\title{
Genetic Evidence for the Adhesion Protein IgSF9/Dasm1 to Regulate Inhibitory Synapse Development Independent of its Intracellular Domain
}

\author{
Archana Mishra, ${ }^{1}$ Matthias H. Traut, ${ }^{1,2}$ Lore Becker, ${ }^{3,4}$ Thomas Klopstock, ${ }^{3,4,5}$ Valentin Stein, ${ }^{2,6}$ and Rüdiger Klein ${ }^{1,5}$ \\ ${ }^{1}$ Department of Molecules-Signaling-Development and ${ }^{2}$ Synaptic Receptor Trafficking Group, Max Planck Institute of Neurobiology, D-82152 Martinsried, \\ Germany, ${ }^{3}$ German Mouse Clinic, Institute of Experimental Genetics, Helmholtz Zentrum München, German Research Center for Environment and Health, \\ D-85764 Neuherberg, Germany, ${ }^{4}$ Department of Neurology, Friedrich-Baur-Institute, Ludwig-Maximilians-University, D-80336 Munich, Germany, \\ ${ }^{5}$ Munich Cluster for Systems Neurology (SyNergy), D-80336 Munich, Germany, and ${ }^{6}$ Department of Physiology II, University of Bonn, D-53115 Bonn, \\ Germany
}

Normal brain function requires balanced development of excitatory and inhibitory synapses. An imbalance in synaptic transmission underlies many brain disorders such as epilepsy, schizophrenia, and autism. Compared with excitatory synapses, relatively little is known about the molecular control of inhibitory synapse development. We used a genetic approach in mice to identify the Ig superfamily member IgSF9/Dasm1 as a candidate homophilic synaptic adhesion protein that regulates inhibitory synapse development. IgSF9 is expressed in pyramidal cells and subsets of interneurons in the CA1 region of hippocampus. Electrophysiological recordings of acute hippocampal slices revealed that genetic inactivation of the IgSF9 gene resulted in fewer functional inhibitory synapses; however, the strength of the remaining synapses was unaltered. These physiological abnormalities were correlated with decreased expression of inhibitory synapse markers in IgSF9 ${ }^{-1-}$ mice, providing anatomical evidence for a reduction in inhibitory synapse numbers, whereas excitatory synapse development was normal. Surprisingly, knock-in mice expressing a mutant isoform of IgSF9 lacking the entire cytoplasmic domain (IgSF9 ${ }^{\Delta \mathrm{C} / \Delta \mathrm{C}}$ mice) had no defects in inhibitory synapse development, providing genetic evidence that IgSF9 regulates synapse development via ectodomain interactions rather than acting itself as a signaling receptor. Further, we found that IgSF9 mediated homotypic binding and cell aggregation, but failed to induce synapse formation, suggesting that IgSF9 acts as a cell adhesion molecule (CAM) to maintain synapses. Juvenile $\mathrm{IgSF}^{-1-}$ mice exhibited increased seizure susceptibility indicative of an imbalance in synaptic excitation and inhibition. These results provide genetic evidence for a specific role of IgSF9 in inhibitory synapse development/ maintenance, presumably by its CAM-like activity.

\section{Introduction}

Excitation in the CNS is governed by glutamatergic pyramidal neurons, whereas inhibition is achieved by GABA releasing (GABAergic) interneurons. Functional circuits depend on the proper balance of synaptic excitation and inhibition to process sensory information and to perform motor and cognitive tasks. Excitatory-inhibitory imbalances and synaptic dysfunction lead to neurological and psychiatric disorders. Whereas a great deal is

\footnotetext{
Received Aug. 28, 2013; revised Feb. 4, 2014; accepted Feb. 11, 2014

Author contributions: A.M., M.T., L.B., T.K., V.S., and R.K. designed research; A.M., M.T., and L.B. performed research; A.M., M.T., L.B., T.K., V.S., and R.K. analyzed data; A.M., V.S., and R.K. wrote the paper.

This work was supported by the Max-Planck Society. L.B. and T.K. received funding from the German Federal Ministry of Education and Research (Grants 01GS0850, 01E00901, and 01KX1012) and the European Union (EUMODIC). We thank Marianne Braun for technical assistance with electron microscopy and Gönül Seyit-Bremer for generating lgsf $9 / 9 \mathrm{~b}$ antibodies and recombinant proteins.

The authors declare no competing financial interests.

Correspondence should be addressed to either of the following: Rüdiger Klein, Department of MoleculesSignaling-Development, Max Planck Institute of Neurobiology, D-82152 Martinsried, Germany, E-mail: rklein@neuro.mpg.de; or Valentin Stein, Institut für Physiologie 2, Universität Bonn, D-53115 Bonn, Germany, E-mail: valentin.stein@ukb.uni-bonn.de.

DOI:10.1523/JNEUROSCI.3671-13.2014

Copyright $\odot 2014$ the authors $\quad 0270-6474 / 14 / 344187-13 \$ 15.00 / 0$
}

known about the molecular control of excitatory synapse formation (Dalva et al., 2007, Paluszkiewicz et al., 2011, Robbins et al., 2010, Ting et al., 2012), less is known about mechanisms regulating inhibitory synapse formation (Fazzari et al., 2010, Lin et al., 2008, Poulopoulos et al., 2009, Takahashi et al., 2012).

Cell adhesion molecules (CAMs) play an important role in the development and maintenance of synapses by assisting in target recognition, initial contact formation, and maturation (de Wit et al., 2011, Krueger et al., 2012, Siddiqui and Craig, 2011). Certain CAMs may perform some of their synaptic functions independently of their intracellular domains, relying primarily on extracellular interactions (Chen et al., 2010, Ko et al., 2011, Soler-Llavina et al., 2011). CAM-mediated synapse formation appears to involve a network of adhesion proteins, so loss of any single synaptogenic protein often leads to subtle defects (Siddiqui and Craig, 2011).

IgSF9, also known as Dasm1 (Shi et al., 2004b), is an Ig superfamily (IgSF) adhesion molecule (Doudney et al., 2002) initially reported to regulate hippocampal neuron differentiation and excitatory synaptic maturation (Shi et al., 2004a, Shi et al., 2004b); however, more recently, we have shown that hippocampal neu- 
ron differentiation in $\mathrm{IgSF}^{-1-}$ mice was normal (Mishra et al., 2008). The Drosophila homolog of IgSF9, Turtle, is required for neural circuitry development and coordinated motor output (Bodily et al., 2001). Turtle regulates dendrite differentiation in sensory neurons in part by mediating dendritic self-avoidance (Long et al., 2009). Turtle also mediates homophilic cell-cell interactions to regulate the tiling of R7 photoreceptor terminals (Ferguson et al., 2009) and acts as a midline attractant for commissural axons (Al-Anzi and Wyman, 2009). IgSF9 in mammals has a close relative termed IgSF9b, which was recently reported to promote inhibitory synapse development (Woo et al., 2013). IgSF9b shRNA knock down in hippocampal interneurons reduced the numbers of inhibitory synapses and the frequency of inhibitory synaptic transmission. The in vivo functions of IgSF9 family proteins remain unknown.

In this study, we analyzed $I g S F 9^{-1-}$ mice and found that IgSF9 promotes inhibitory, but not excitatory, synapse development in CA1 pyramidal neurons. In contrast, newly generated IgSF9 ${ }^{\Delta \mathrm{C} / \Delta \mathrm{C}}$ knock-in mice that express a mutant form of IgSF9 lacking its cytoplasmic tail had no defects in inhibitory synapse development, indicating that IgSF9 regulates synapse development via ectodomain interactions rather than relying on intracellular interactions with cytoplasmic proteins. IgSF9 mediates homotypic cell aggregation, but is unable to induce synapse formation, suggesting that IgSF9 acts as CAM to maintain synapses. Juvenile $I g S \mathrm{SP}^{-1}$ mice exhibit increased seizure susceptibility indicative of loss of synaptic inhibition. These results provide genetic evidence for a specific role of IgSF9 in inhibitory synapse development and/or maintenance.

\section{Materials and Methods}

Generation of IgSF9 mutant mice. IgSF9 knock-out mice have been described previously (Mishra et al., 2008). IgSF9 mice lacking the cytoplasmic tail (IgSF9- $\Delta$ C mice) were generated by amplifying a $4 \mathrm{~kb}$ (short arm with a stop codon introduced at the $3^{\prime}$ end) and a $5 \mathrm{~kb}$ (long arm) genomic fragmentssurrounding exon 18 of the IgSF9 gene by PCR from embryonic day 14 (E14) embryonic stem (ES) cell genomic DNA. Homology arms were subcloned into a pBluescript SK vector containing the thymidine kinase cassette. Primers were designed to incorporate cleavage sites for restriction enzymes (Sall and SpeI for the $4 \mathrm{~kb}$ fragment; XhoI for the $5 \mathrm{~kb}$ fragment) for ligation into the targeting vector. After amplification by PCR, all exons and exon-intron borders were sequenced. A replacement-type targeting vector was generated by subcloning a loxPflanked cassette containing the PGK-driven neomycin (neo) gene between the two homology arms. The targeting vector was linearized with NotI and electroporated into E14 ES cells. Resistant cells were selected in the presence of G418, DNA was isolated, and homologous recombinants were confirmed by Southern blotting. All of the experiments were performed with mice of either sex in a mixed $129 / \mathrm{SvEv} \times$ C57BL/6 background.

To visualize individual hippocampal pyramidal and GABAergic neurons in vivo, IgSF9 ${ }^{+/-}$mice were crossed with the transgenic mouse lines GFP-M (Feng et al., 2000) and GAD65-GFP (LopezBendito et al., 2004) to generate $\operatorname{IgSF}^{+/-}$:GFP-M and $\operatorname{IgSF} 9^{+/-}$: GAD65-GFP mice, respectively. When back crossed with $\mathrm{IgSF9}^{+1-}$ mice, these trans-heterozygotes produced $\mathrm{IgSF}^{+/+}$control and IgSF9- /- littermates with one copy of the respective transgene.

All animal use was performed in compliance with institutional and appropriate governmental policies.

Genotyping. The genotypes of mutant mice were determined by PCR and confirmed by Southern blot analysis of genomic DNA prepared from tail biopsy samples. Routine genotyping through PCR was performed with genomic DNA using specific oligonucleotide primers for the IgSF9 wild-type allele (F1, 5' -AAGGGAAAGAGCAGCCTAGGCAAGGCG-3', and R1, 5'-CCTTCGCTGATAGCTACGTCAGTGACCC-3'). For the targeted allele, a primer was designed from within the neomycin resis- tance gene (N1，5'-TTGAAAACCACACTGCTCGATCCGGAACCC$\left.3^{\prime}\right)$. The three primers were used in a multiplex PCR with the following amplification conditions: $94^{\circ} \mathrm{C}$ for $3 \mathrm{~min}$ and 30 cycles of $94^{\circ} \mathrm{C}$ for $30 \mathrm{~s}$, $61^{\circ} \mathrm{C}$ for $30 \mathrm{~s}$, and $72^{\circ} \mathrm{C}$ for $40 \mathrm{~s}$. Amplification products were resolved on a $2 \%$ agarose gel. The PCR product for the wild-type allele was $358 \mathrm{bp}$ and for the targeted allele was $426 \mathrm{bp}$. The presence of Thy1-GFP and GAD65-GFP transgenes was detected by using specific primers for GFP (F, 5'-GCGGATCTTGAAGTTCACCTTGATGCC-3'; R, 5' -GCACGA CTTCTTCA AGTCCGCCATGCC-3') with the following amplification conditions: $94^{\circ} \mathrm{C}$ for $2 \mathrm{~min}$, and 35 cycles of $94^{\circ} \mathrm{C}$ for $1 \mathrm{~min}, 68^{\circ} \mathrm{C}$ for 1 $\min$, and $72^{\circ} \mathrm{C}$ for $1 \mathrm{~min}$.

Single-cell RT-PCR analysis. Hippocampi were dissected out from P15 GAD65-GFP brains and cells were digested with prewarmed $0.25 \%$ trypsin containing 1 mM EDTA (25200-056; Life Technologies) for 20 min at $37^{\circ} \mathrm{C}$, followed by DNase (DN25; Sigma-Aldrich) treatment for $5 \mathrm{~min}$ at room temperature. After trituration with glass pipettes, the cell suspension was passed through $40 \mu \mathrm{m}$ cell strainer (352340; BD Falcon) and washed twice with Hank's Balanced Salt Solution (24020; Invitrogen) to give a single cell suspension. Single GFP-positive green fluorescent cells were individually picked using a mouth pipette under a fluorescence stereomicroscope (M205 FA; Leica). To amplify the RNA from single cells, the Qiagen OneStep RT-PCR Kit was used according to manufacturer's instructions. For the RT reaction, specific primers for IgSF9, GAPDH, calcium-calmodulin kinase II alpha (CaMKII $\alpha)$, and GFAP were used: IgSF9-F1 5' -CTACGCCAGAGTCTGCTCTGG-3', IgSF9-R1 5'-ATAGCAGAGTAGCCTGTTCAGG-3'; GAPDH-F1 5'-GATGGCC CCTCTGGAAAGCT-3', GAPDH-R1 5'-AGCCGTATTCATTGTCATACC-3'; CaMKII $\alpha$-F1 5'-AAGCCCCAAGCTCGTCAGTCAAGCC-3', CaMKII $\alpha$-R1 $5^{\prime}$-AGGTATCCAGGTGTCCCTGCGAACC-3'; GFAP-F1 5'-AGAACAACCTGGCTGCGTAT-3'，GFAP-R1 5'-CTCACATCAC CACGTCCTTG- $3^{\prime}$. Specific products were further amplified in a second PCR step using New England Biolabs TAQ polymerase and nested primers for each gene: IgSF9-F2 5'-CTCTGCATTACAGACATCAGC-3', IgSF9-R2 5'-TCTGCGGAAAGCTAGGAATTCC-3'; GAPDH-F2 $5^{\prime}$ AGCTGAACGGGAAGCTCACTG-3', GAPDH-R2 5' -AGTTGTCATTGAGAGCAATGC-3'; CaMKII $\alpha$-F2 $5^{\prime}$-ATCACCAGAAGCTGGAGC GTGAGGC-3', CaMKII $\alpha$-R2 $5^{\prime}$-TCTGGTGACAGTGTAGCACAGCCTCC-3'; GFAP-F2 5'-GAACCCGTCTTCCATCGTTA-3', GFAP-R2 5'-AGAAAGGTTGAATCGCTGGA-3' . All selected cells were negative for GFAP (an astrocyte marker) and CaMKII $\alpha$ (a pyramidal neuron marker). The cycling conditions for the RT-PCR were $30 \mathrm{~min}$ at $50^{\circ} \mathrm{C}, 15$ min at $94^{\circ} \mathrm{C}, 40$ cycles of $30 \mathrm{~s}$ at $94^{\circ} \mathrm{C}, 40 \mathrm{~s}$ at $60^{\circ} \mathrm{C}$, and $1 \mathrm{~min}$ at $72^{\circ} \mathrm{C}$, followed by $10 \mathrm{~min}$ at $72^{\circ} \mathrm{C}$. For the nested PCR, we used $3 \mathrm{~min}$ at $94^{\circ} \mathrm{C}$, 40 cycles of $30 \mathrm{~s}$ at $94^{\circ} \mathrm{C}, 40 \mathrm{~s}$ at $60^{\circ} \mathrm{C}$, and $1 \mathrm{~min}$ at $72^{\circ} \mathrm{C}$, followed by 10 $\min$ at $72^{\circ} \mathrm{C}$.

Antibodies. IgSF9 C-terminal domain-specific antibody has been described previously (Mishra et al., 2008). To generate N-terminal specific antibodies, IgSF9 cDNA encoding the whole extracellular domain (excluding the signal peptide, i.e., amino acids 25-706) was subcloned into pET-28 plasmid vector (Novagen). The fusion protein $\mathrm{His}_{6}$-IgSF9 $\left(\mathrm{N}_{25-706}\right)$ was purified and used to immunize rabbits. The IgG-enriched fraction of the polyclonal rabbit antisera was used to detect IgSF9 protein by Western blotting and immunostaining (IgSF9-ECD). Other antibodies used were as follows: cholecystokinin (AB1973; Millipore), CTIP2 (ab18465; Abcam), EGFP (mouse monoclonal MAB3580; Millipore; rabbit polyclonal RDI GRNFP4abr, RDI), GAD67 (MAB5406; Millipore), Gephyrin (147011; Synaptic Systems), Map2 (sc-5359; Santa Cruz Biotechnology), parvalbumin (235; Swant), PSD95 (p-246; SigmaAldrich), and VGAT (131002; Synaptic Systems).

Histology, immunohistochemistry, and image acquisition. Histology and immunostainings were done as described previously (Mishra et al., 2008). Briefly, mice were perfused with PBS and 4\% paraformaldehyde, followed by overnight postfixation. Immunostaining was performed on $50-\mu \mathrm{m}$-thick vibratome sections that were blocked in $5 \%$ BSA and 5\% donkey serum, permeabilized in $0.3 \%$ Triton X-100 in PBS, and incubated with the primary antibody at $4^{\circ} \mathrm{C}$ for $48 \mathrm{~h}$. The sections were washed $3 \times$ in PBS with $0.1 \%$ Triton $\mathrm{X}-100$ and incubated with fluorophore-conjugated secondary antibody (Jackson ImmunoResearch) at $4^{\circ} \mathrm{C}$ overnight. Sections were washed and 
$\mathbf{A}$

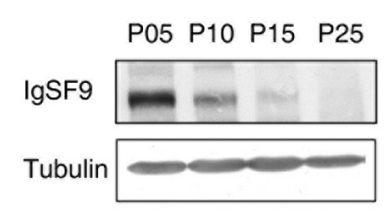

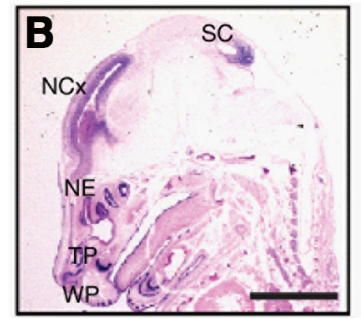
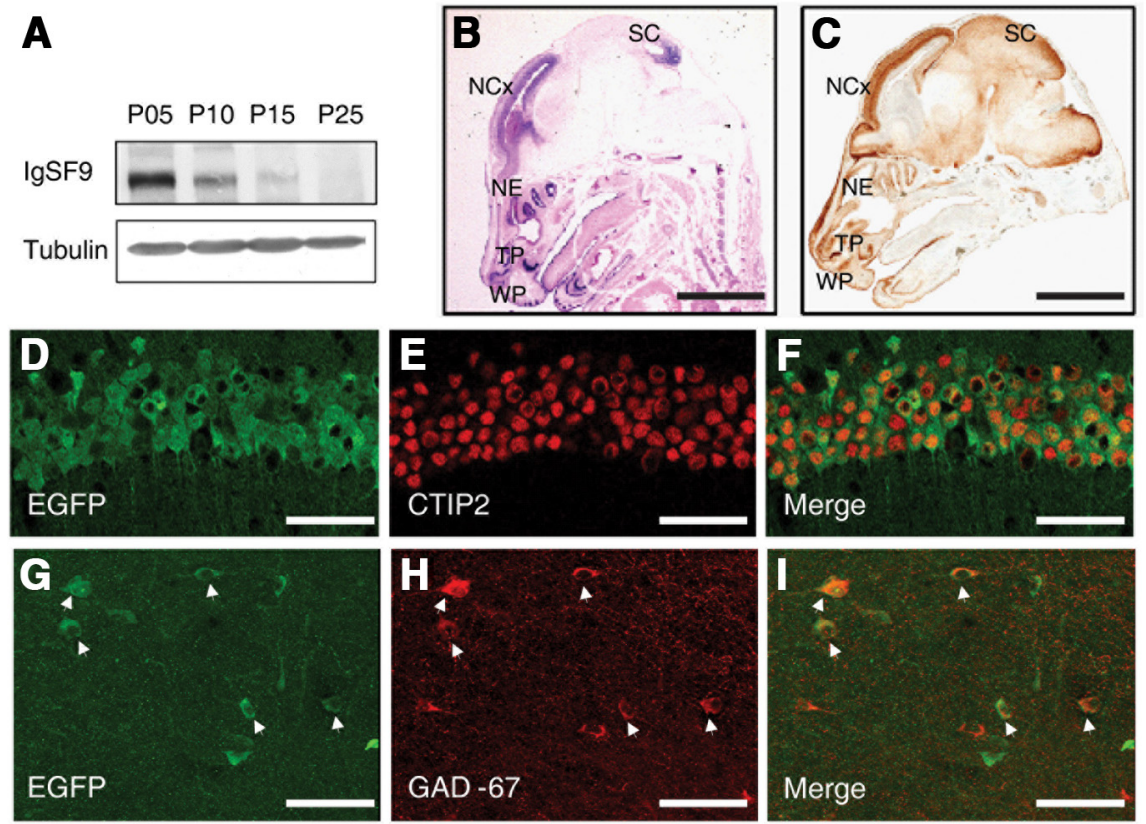

J
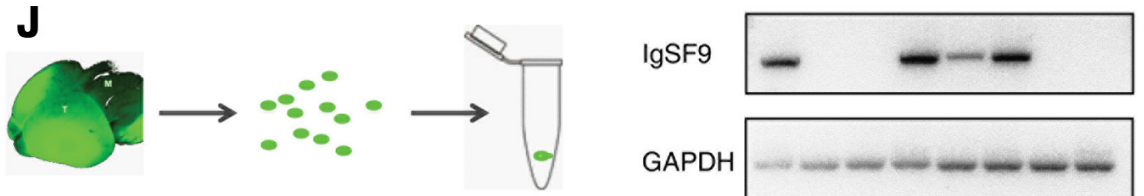

GAPDH
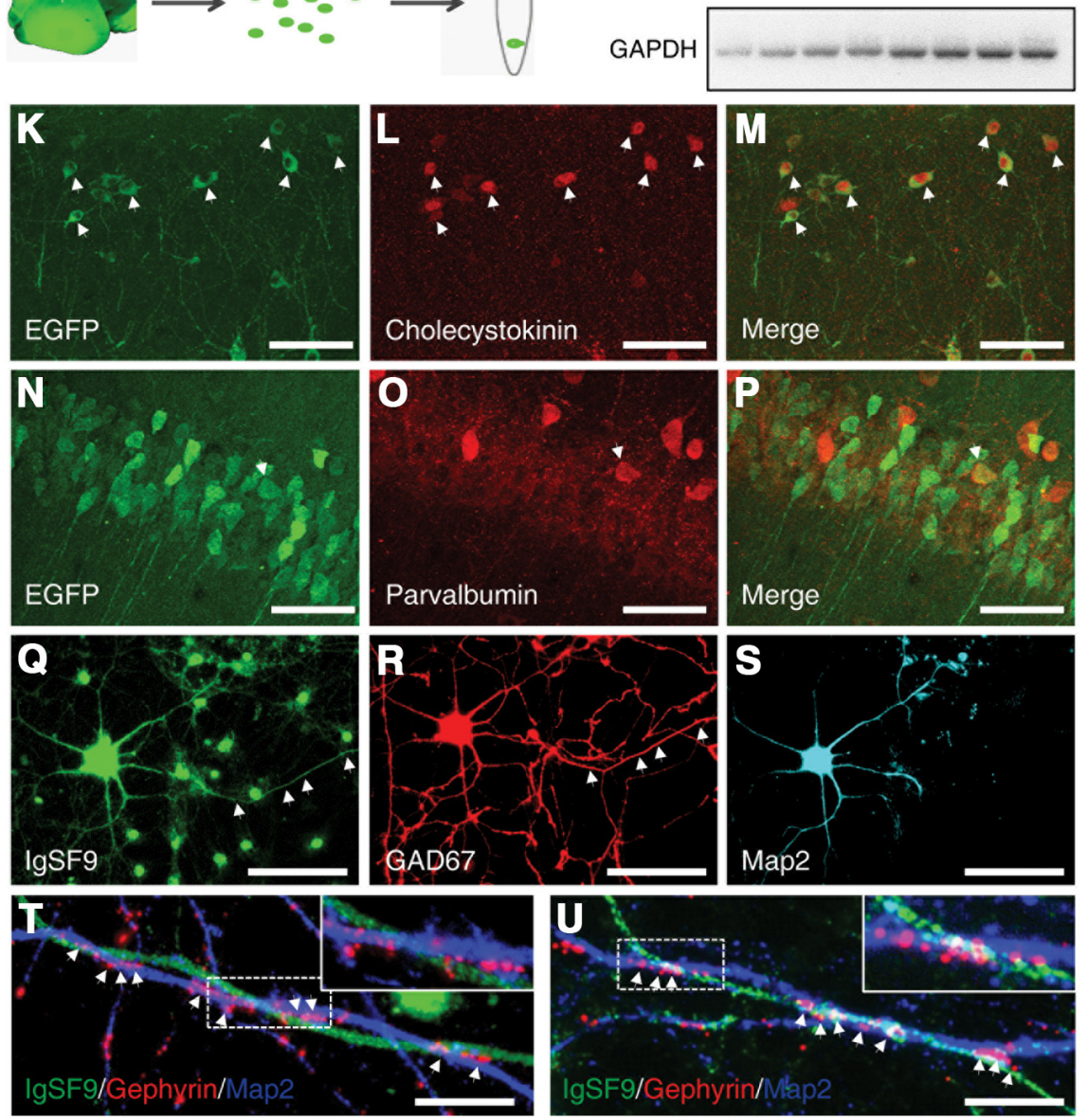

Figure 1. Expression of IgSF9 in the hippocampus during postnatal development. $\boldsymbol{A}$, Developmental profile of IgSF9 expression shown by lectin pull-down of mouse hippocampal lysates and Western blot analysis using an antibody against the intracellular domain of IgSF9 (top). Equal amounts of protein were used as input for the pull-down, as confirmed by loading equal amounts of total protein and blotting with antitubulin antibody (bottom). B, IgSF9 in situ hybridization analysis of a sagittal section of an E15 mouse embryo showing expression in neocortex (NCX), posterior part of superior colliculus (SC), whisker pads (WP), nasal epithelium (NE), and tooth primordia (TP). C, EGFP immunostaining of a similar section of an E15 embryo from the transgenic lgSF9-EGFP mounted using aqueous mounting medium with antifading reagent (S3023; Dako).

Fluorescence confocal images were acquired using TCS SP2 (Leica Microsystems) and Fluoview FV 1000 (Olympus) confocal microscopes using a $63 \times 1.35$ oil-immersion objective. Apical secondary or tertiary dendrites of CA1 pyramidal neurons were analyzed for spine density and dimensions using MetaMorph image analysis software (Molecular Devices). Images from GAD67-stained sections were thresholded by subtracting the background fluorescence and selection of appropriate clusters was confirmed visually before measuring the fraction of the area covered by GAD67-stained clusters (total image area $11232.6 \mu \mathrm{m}^{2}$ ).

Hippocampal neuron culture and immunostaining. Hippocampi from E18 mice were separated from diencephalic structures and digested individually with $0.25 \%$ trypsin containing $1 \mathrm{~mm}$ EDTA for $20 \mathrm{~min}$ at $37^{\circ} \mathrm{C}$. Neurons were plated in 24-well plates $(40,000$ per well) on coverslips coated with poly-D-lysine (1 $\mathrm{mg} / \mathrm{ml})$ and laminin $(5 \mu \mathrm{g} / \mathrm{ml})$, in neurobasal medium supplemented with B27 containing $0.5 \mathrm{~mm}$ glutamine (all reagents from Invitrogen). Neurons were cultured for $3 \mathrm{~d}$ in vitro (DIV) or 14 DIV when they were fixed and stained as described previously (Mishra et al., 2008) using anti-IgSF9-ECD antibody for endogenous expression; anti-GAD-67 (1:1000) antibody for axon-tracing; anti-GAD-67, anticholecystokinin (anti-CCK; 1:300), and anti-Map2 (1:500) antibodies for dendritic morphology; and anti-Gephyrin and antiVGAT antibody (1:500) for inhibitory synapse density. Images were acquired using a digital camera (SpotRT; Diagnostic Instruments) attached to an epifluorescence microscope (Zeiss) equipped with $20 \times 0.8,40 \times 1.4$, and $63 \times 1.4$ numerical aperture oil-immersion

$\longleftarrow$

mouse line. $\boldsymbol{D}-\boldsymbol{F}$, Immunostaining in the stratum pyramidale layer of CA1 in the hippocampus of P15 lgSF9-EGFP transgenic mice with antibodies against EGFP $(\boldsymbol{D})$, the pyramidal neuron marker CTIP2 $(\boldsymbol{E})$, and the merged image $(\boldsymbol{F})$. The quantification revealed that $77 \%$ of $\mathrm{CTIP2}{ }^{+}$cells were lgSF9 ${ }^{+}(2408$ cells counted in total from $n=3$ mice). $\mathbf{G}-\mathbf{I}$, Staining of IgSF9EGFP-positive cells $(\boldsymbol{G})$ with the interneuron marker GAD-67 $(\boldsymbol{H})$ in the stratum radiatum (merged image in $\boldsymbol{I}$ ). Arrows show costained neurons. For the quantification, 483 cells were counted in total from $n=3$ mice. $J$, Single cell RT-PCR shows expression of IgSF9 (top) and GAPDH (bottom) in GFP-positive interneurons dissociated and hand-picked from hippocampi of P15 GAD65-GFP transgenic mice. Nine out 20 cells were scored positive for lgSF9. $\boldsymbol{K}-\boldsymbol{P}$, Costaining of IgSF9-EGFP $(\boldsymbol{K}, \boldsymbol{N})$ with cholecystokinin-positive interneurons $(\boldsymbol{L})$ in the stratum lacunosum-moleculare and parvalbumin-positive interneurons $(\mathbf{0})$ in the stratum radiatum of hippocampal CA1. Q-S, Localization of IgSF9 in interneurons $(\boldsymbol{Q})$ with enriched expression in GAD-67-positive axons ( $\boldsymbol{R}$; arrows) and Map2-positive dendrites (S). $\boldsymbol{T}, \boldsymbol{U}$, Presence of IgSF9 (green axons) at GABAergic synapses revealed by gephyrin staining (red puncta shown by arrows) on Map2-stained dendrites (blue). Insets show synaptic sites indicated by stippled boxes. Scale bars: $\boldsymbol{B}, \boldsymbol{C}, 2 \mathrm{~mm}$; D-I, K-S, $50 \mu \mathrm{m} ; \boldsymbol{I}, \boldsymbol{U}, 10 \mu \mathrm{m}$ 
objectives (Plan-Apochromat; Zeiss). Total length and number of branches of the longest neurite (axon) were measured using MetaMorph image analysis software (Molecular Devices). Sholl analysis was performed using the ImageJ plugin. Regions of primary and secondary dendrites were randomly selected and the density of synaptic protein puncta was analyzed using MetaMorph.

Electron microscopy. Mice were perfused with $0.9 \% \mathrm{NaCl}$, followed by $2.5 \%$ glutaraldehyde and $1 \%$ paraformaldehyde in $0.1 \mathrm{M}$ sodium cacodylate buffer, $\mathrm{pH}$ 7.4. After overnight fixation, $100 \mu \mathrm{m}$ vibratome sections were cut and CA1 region of the hippocampus was trimmed under microscope. Ultrathin sections $(60 \mathrm{~nm})$ were cut, dehydrated, and embedded in Epon, stained with uranyl acetate and lead citrate, and photographed at $8000 \times$ magnification (EM-10; Zeiss). Negatives were scanned and images were analyzed using MetaMorph image analysis software (Molecular Devices). Quantification of synapse density was performed on at least 120 photographs from four mice per genotype by individuals blinded to the genotype of the mice.

Surface staining and Fc-binding assay. HEK293T cells were transiently transfected using $\mathrm{Fu}-$ GENE6 transfection reagent (Promega) with IgSF9-FL-EGFP or IgSF9b-FL. Surface expression of IgSF9-FL-EGFP was assessed by incubating the cells with IgSF9-ECD in Opti-MEM (Life Technologies) at room temperature for 1 $\mathrm{h}$ without permeabilization. Total expression was revealed by the following fixation: $4 \%$ paraformaldehyde, permeabilization with $0.1 \%$ Triton X-100 (Sigma-Aldrich) in PBS, and staining with anti-GFP antibody. For the binding assay, human-Fc alone or IgSF9b-Fc were preclustered with goat-anti-human-IgG (Fc-fragment specific) for $1 \mathrm{~h}$ at room temperature, followed by incubation with transfected cells in Opti-MEM (20 min at room temperature), washed $3 \times$ in PBS, fixed, and labeled with anti-rabbit-Cy3 (all reagents from Jackson ImmunoResearch).

Cell aggregation assay. HEK293T cells were transiently transfected using calcium phosphate with pEGFP-N1 (Clontech) and N-cadherin, IgSF9-FL-EGFP, or IgSF9- $\Delta$ C-EGFP. Aggregation assays were performed as described previously (Karaulanov et al., 2006): Twenty-four hours after transfection, cells were dissociated in PBS-2 mM EDTA and $2.5 \times 10^{5}$ cells $/ \mathrm{ml}$ aggregated in suspension with orbital shaking (125 $\mathrm{rpm}$ ) in BSA-coated 24 -well plates at $37^{\circ} \mathrm{C}$ and $5 \% \mathrm{CO}_{2}$ for $48 \mathrm{~h}$. Photographs were taken with an inverted fluorescence microscope (Leica) connected to a cooled digital color camera (DP70; Olympus).

Mixed culture assay. Coculture experiments were as described previously (Biederer and Scheiffele, 2007). Cos-7 cells transfected with EGFP, Neuroligin-2 with EGFP, Neurexin-1 $\beta$-EGFP, or IgSF9-FL-EGFP were seeded on top of DIV 12-14 hippocampal neurons and further cultured for $2 \mathrm{~d}$. Transfection into Cos-7 cells was done using Lipofectamine-2000 (11668-027; Life Technologies). The cells were fixed and stained with antibodies against EGFP, VGAT/gephyrin, and Map2 as described previously (Biederer and Scheiffele, 2007).

Slice preparation. Animals were anesthetized with isoflurane (Baxter) and decapitated. Brains were removed quickly and chilled in cooled $\left(4^{\circ} \mathrm{C}\right)$ artificial CSF (ACSF) containing the following (in mM): 130.9 $\mathrm{NaCl}, 2.75 \mathrm{KCl}, 1.43 \mathrm{MgSO}_{4}, 2.5 \mathrm{CaCl}_{2}, 1.1 \mathrm{NaH}_{2} \mathrm{PO}_{4}, 28.8 \mathrm{NaHCO}_{3}$, and $11.1 \mathrm{D}$-glucose, osmolarity 315-325 mOsm/L. Hippocampal slices (400 $\mu \mathrm{m}$ ) were cut either horizontally on postnatal days 5 (P5) to P6 or transversally on P15-P20 with a vibratome (VT1200S; Leica). Before re-
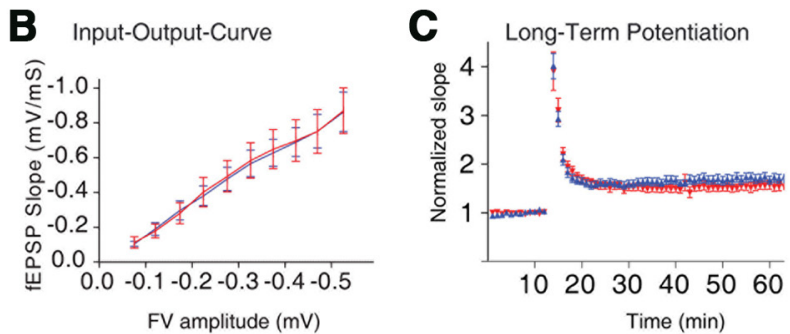

\section{E}

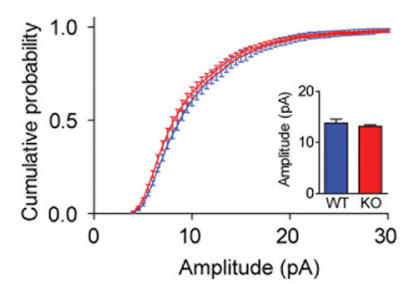

$\mathbf{F}$

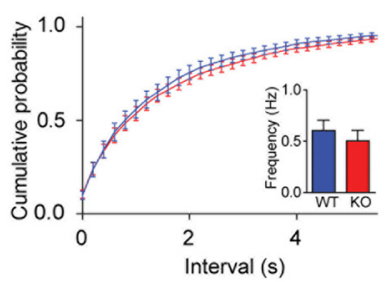

H Paired Pulse Stimulation

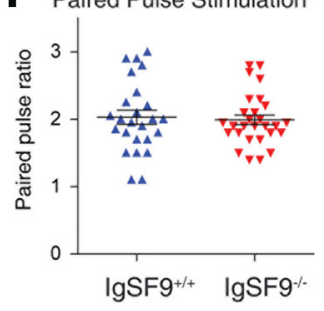

Figure 2. IgSF9 is dispensable for proper function of excitatory synapses. Basal synaptic transmission is unaltered in lgSF9- ${ }^{-1-}$ mice. , Sample traces of $\mathrm{fEPSP}$ of $/ g S F 9^{+}++$and $/ g S F 9^{-1-}$ mice. $\boldsymbol{B}$, Input- output curves of fEPSPs of $/ g S F 9^{+1+}$ and $/ g S F 9^{-1-}$ mice. The

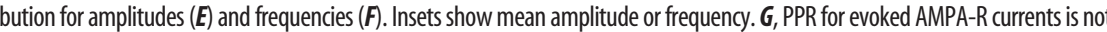
altered. Sample traces of paired pulse stimulation with an interevent interval of $40 \mathrm{~ms}$ in $/ g S F 9^{+/+}$and $/ g S F 9^{-/-}$mice. $\boldsymbol{H}$, Quantification of the PPR for the $40 \mathrm{~ms}$ interval. Error bars indicate SEM in all graphs.

cording, slices were kept for $30 \mathrm{~min}$ at $32^{\circ} \mathrm{C}$ and subsequently stored at room temperature in ACSF continuously gassed with carbogen.

Electrophysiology. All recordings were performed using a Multiclamp $700 \mathrm{~B}$ amplifier (Molecular Devices). Data were digitized using a Digidata 1440A (Molecular Devices). Pipettes (3-5 M $\Omega$ ) were pulled from borosilicate glass (Science Products). Inputs from CA3 to CA1 were severed to prevent propagation of epileptiform activity.

Extracellular recordings. Synaptic responses were evoked by stimulating the Schaffer collaterals at $0.1 \mathrm{~Hz}$ with $0.2 \mathrm{~ms}$ pulses. Field EPSPs (fEPSPs) were recorded in the stratum radiatum of the CA1 region using glass microelectrodes (Science Products) filled with ACSF. All experiments were performed at room temperature $\left(22-24^{\circ} \mathrm{C}\right)$. fEPSP slopes were used as a measure of dendritic activity and determined between 20 and $80 \%$ of the maximum field amplitude. fEPSP slopes acquired over 2 min were averaged. For long-term potentiation (LTP) recordings, baseline recordings were obtained for $20 \mathrm{~min}$. LTP was induced by two trains of $0.2 \mathrm{~ms}$ pulses at $100 \mathrm{~Hz}$ for $1 \mathrm{~s}$ with an intertrain interval of $20 \mathrm{~s}$. Postinduction responses were monitored for $60 \mathrm{~min}$.

Whole-cell recordings. Whole-cell recordings were obtained from CA1 pyramidal cells, which were visualized using differential interference contrast infrared video microscopy.

Excitatory synaptic transmission. Whole-cell patch recordings were obtained in ACSF supplemented with picrotoxin (PTX; $100 \mu \mathrm{M}$ ) to block $\mathrm{GABA}_{\mathrm{A}}$ receptors. Glass electrodes were filled with an internal solution containing the following (in mM): 150 Cs-gluconate, $8 \mathrm{NaCl}, 2 \mathrm{MgATP}$, 10 HEPES, 0.2 EGTA, 0.1 spermine, and 5 QX-314, pH 7.2. Paired-pulse facilitation was determined as the ratio of the AMPA EPSC of the second pulse to the AMPA EPSC of the first pulse with an interstimulus interval of $40 \mathrm{~ms}$. Miniature EPSCs (mEPSCs) were recorded at $-70 \mathrm{mV}$ in ACSF 
A

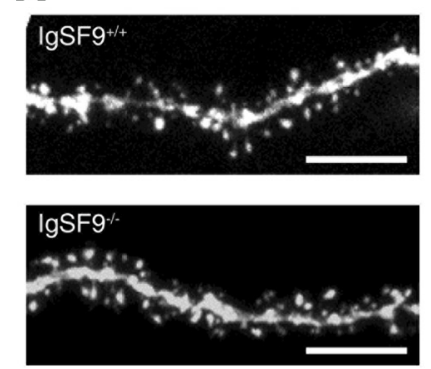

E
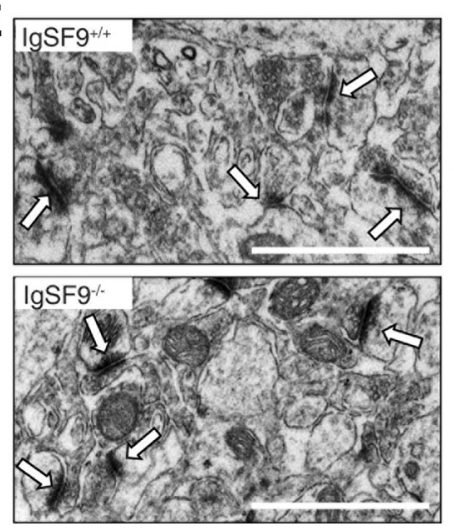

B

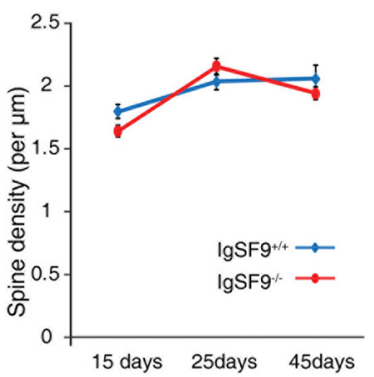

$F$

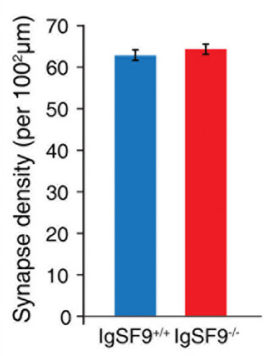

G
C
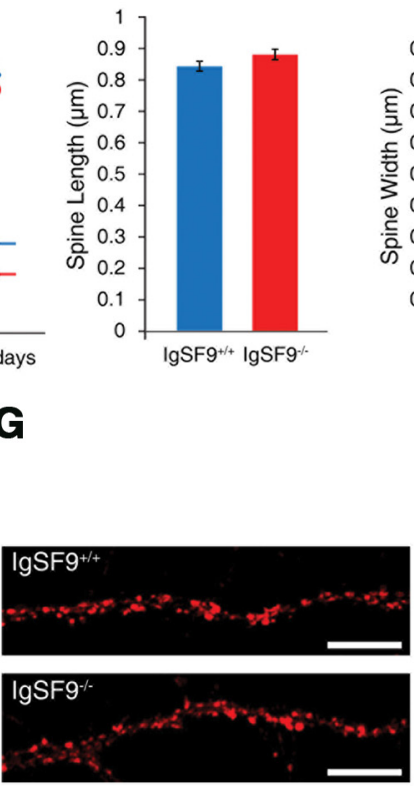

D

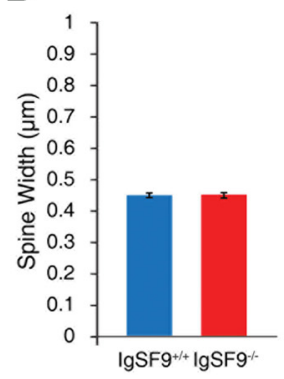

H

Figure 3. Normal spine and excitatory synapse development in the hippocampus of IgSF9- ${ }^{-1}$ mice. $A$, Representative confocal images of CA1 pyramidal neuron apical dendrites harboring spines in control transgenic GFP-M mice (Feng et al., 2000; top) and IgSF9 ${ }^{-1-}$;GFP-M littermates (bottom). Scale bar, $5 \mu \mathrm{m}$. B, Quantification of spine densities (number per micrometer dendrite length) at the indicated postnatal stages in $1 \mathrm{gSF} 9^{-1}$ - and littermate controls (on average, a total of 30 secondary/tertiary dendrites of $30-60 \mu \mathrm{m}$ length from $n=3$ mice counted per data point; $p>0.05$ for P15, P25, and P45, respectively; Student's $t$ test). $\boldsymbol{C}, \boldsymbol{D}$, Quantification of spine length $(\boldsymbol{C} ; p>0.05)$ and spine width $(\boldsymbol{D} ; p>0.05$, Student's $t$ test; on average total of 300 spines from $n=3$ mice counted per genotype). $\boldsymbol{E}$, Electron micrographs of the hippocampal CA1 stratum radiatum area in P25 littermate controls (top) and /gSF9 ${ }^{-1-}$ (bottom). Excitatory asymmetric synapses are marked by arrows. Scale bar, $1 \mu \mathrm{m}$. $\boldsymbol{F}$, Quantification of excitatory synapse densities (on average, $>7500$ synapses from $n=4$ mice per genotype, $p>0.05$, Student's $t$ test). $\mathbf{G}$, Representative photomicrographs showing PSD-95 immunostaining on hippocampal neurons cultured for $21 \mathrm{~d}$ and derived from the indicated embryos. Scale bar, $10 \mu \mathrm{m}$. $\boldsymbol{H}$, Quantification of the PSD-95 puncta density performed on segment $(40-50 \mu \mathrm{m})$ of primary and secondary dendrites in the cultured neurons ( $n=20$ cells per genotype; $p>0.05$, Student's $t$ test). Values represent mean \pm SEM of three individual experiments.

supplemented with of TTX $(0.2 \mu \mathrm{M})$, PTX $(100 \mu \mathrm{M})$, and trichlormethiazide $(250 \mu \mathrm{M})$ to increase mEPSC frequency.

Inhibitory synaptic transmission. IPSCs were recorded at a $-70 \mathrm{mV}$ holding potential using a high chloride internal solution containing the following (in $\mathrm{mm}$ ): $90 \mathrm{CsCl}, 20 \mathrm{Cs}$-gluconate, $8 \mathrm{NaCl}, 2 \mathrm{MgCl}_{2}, 10$ HEPES, 1 EGTA, and 2 QX-314, pH 7.2, $290 \mathrm{mOsm} / \mathrm{L}$. Spontaneous IPSCs (sIPSCs) were recorded in ACSF supplemented with NBQX (10 $\mu \mathrm{M})$ to block AMPA-Rs. To isolate mIPSCs, ACSF was additionally supplemented with TTX $(0.2 \mu \mathrm{M})$ to block action potentials. The paired pulse ratio (PPR) was determined as the ratio of the IPSC amplitude of the second pulse to the IPSC amplitude of the first pulse with an interstimulus interval of $40 \mathrm{~ms}$.

Behavior experiments. Seizures were induced by intraperitoneal injection of pentylenetetrazol (PTZ) at a dose of $45 \mathrm{mg} / \mathrm{kg}$ body weight in 3 -week-old mice and video monitored for $30 \mathrm{~min}$ after injection. Different behaviors (four different stages of seizure activity according to Weiergraber et al. (2006) and latencies (respective time after injection) were recorded. Briefly, mice show flattening of the body followed by partial myocloni and whole-body myocloni. The next phase is the seizure state with convulsions and loss of upright position. Some animals develop tonic-clonic seizures. All observations were recorded by two people in parallel and averaged afterward. The genotype was unknown to both observers at the time of the test.

Statistical analysis. Results were obtained from at least three independent experiments. Data are presented as mean \pm SEM. Comparisons between groups were analyzed by Student's $t$ test, or the KolmogorovSmirnov (K-S) test, as indicated. Significance was accepted for values where ${ }^{*} p \leq 0.05,{ }^{* *} p \leq 0.01$, and ${ }^{* * *} p \leq 0.001$. For the K-S test, the significance level was 0.01. mEPSCs, sIPSCs, and mIPSCs were analyzed offline with customized software using a threshold of $5 \mathrm{pA}$ (mEPSCs) and
$15 \mathrm{pA}$ (mIPSCs/sIPSCs). For minianalysis, histograms were derived from 150 to 200 events per cell. Averaged cumulative distributions were calculated from normalized histograms. Because the K-S test is only appropriate for testing data against a continuous distribution, 25 events were chosen randomly from each cell and a continuous cumulative probability functions was calculated from these events.

\section{Results}

IgSF9 is expressed in hippocampal pyramidal cells and interneurons

To gain insight into the role of IgSF9 in postnatal hippocampus development, we tested the expression of IgSF9 by Western blot analysis. IgSF9 is highly expressed during the first postnatal week and its levels decline over the following 2 weeks (Fig. 1A). To assess the cellular distribution of IgSF9, we used IgSF9-EGFP transgenic mice that express EGFP under the control of IgSF9 regulatory elements (www.gensat.org). Transgenic expression of EGFP (Fig. 1C) closely matched the pattern of expression observed by in situ hybridization of E15 brain sections (Fig. 1B), in whichexpression was particularly high in neocortex, the posterior part of the superior colliculus, whisker pads, nasal epithelium, and tooth primordia. In hippocampal sections from P15-P20 brains, IgSF9-positive cells were present in all layers of the CA1 region. In the stratum pyramidale, most pyramidal neurons marked by CTIP2 expression (Williams et al., 2011) also expressed IgSF9 (77\%; Fig. 1D-F). In strata radiatum and lacunosum moleculare, IgSF9-positive cells were immunopositive for the interneuron marker GAD-67 (Vullhorst et al., 2009; 69\% of 
IgSF9 ${ }^{+}$cells coexpressed GAD-67; 37\% of $\mathrm{GAD}^{+} 7^{+}$cells coexpressed IgSF9; Fig. 1GI). Expression of IgSF9 in GABAergic neurons was confirmed by single-cell RT-PCR analysis using the GAD-65-GFP transgenic line (Lopez-Bendito et al., 2004). Approximately half of the GFP-positive interneurons were also positive for IgSF9 mRNA (Fig. 1J), whereas, as expected, none scored positive for CaMKII mRNA (data not shown). We further investigated which specific classes of GABAergic neurons expressed IgSF9. We found that IgSF9 was expressed by many CCK-expressing, but not by parvalbumin-expressing, basket cells ( $89 \%$ and $14 \%$, respectively; $n=500$ and 300 cells, respectively, were counted in total from $n=3$ mice; Fig. $1 K-P)$.

To visualize the subcellular location of endogenous IgSF9, we immunostained cultured hippocampal neurons with antiIgSF9 antibodies. Although the signal in dendrites of most neurons in culture was rather diffuse and weak, IgSF9 appeared to be enriched in the distal axons of GAD $67^{+}$interneurons (Fig. 1Q-S) and to be present at inhibitory synaptic sites as revealed by gephyrin staining on a contacting dendrite (Fig. 1T-U). The axonal staining was specific, because it was absent in IgSF9 $^{-1-}$ neurons (data not shown). These results raised the possibility that IgSF9 has a role at inhibitory synapses.

\section{Excitatory synaptic transmission and plasticity is unaffected in $\mathrm{IgSF}^{-/-}$ mice}

Because IgSF9 had previously been implicated in the maturation of excitatory synapses in hippocampal slices (Shi et al., 2004a), we first investigated whether genetic loss of IgSF9 in vivo might affect function and/or plasticity of excitatory synapses. Therefore, we tested basal synaptic transmission in $I g S F 9^{-/-}$mice by comparing size of the presynaptic fiber volley (input) with the slope of the fEPSP in the stratum radiatum of CA1 (Fig. $2 A, B$ ). There were no significant differences in the input-output curves between $\mathrm{IgSF}^{-1-}$ mice and their wild-type littermates (Fig. $2 B$ ), indicating normal basal synaptic transmission in IgSF9 ${ }^{-1-}$ mice. Next, we tested whether the loss of IgSF9 affects synaptic plasticity. In a blind fashion, we compared the magnitude of LTP induced by brief tetanic stimulation using field potential recordings in the CA1 area of the hippocampus. No difference in LTP was observed when comparing IgSF9 ${ }^{-1-}$ with wild-type littermates (mean EPSP slope relative to baseline 50 -60 min after LTP induction was $1.60 \pm 0.05$ in IgSF9 $^{-1-}$ mice, $n=14$, vs $1.53 \pm 0.05$ in littermate controls, $n=$ $16 ; p>0.05$, Student's $t$ test; Figure $2 C$ ).

A previous study (Shi et al., 2004a) had shown that shRNA knock down of IgSF9 decreased the AMPA-R-mediated synaptic transmission by $50 \%$, whereas it had no effect on NMDA-R-mediated synaptic transmission. To further evaluate the effect of IgSF9 loss on AMPA-R-mediated currents, miniature IPSCs

spontaneous IPSCs

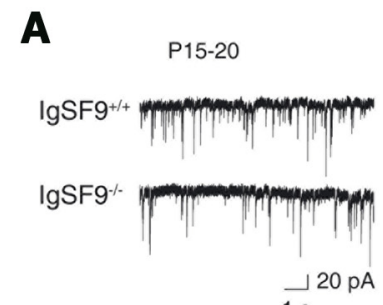

$1 \mathrm{~s}$
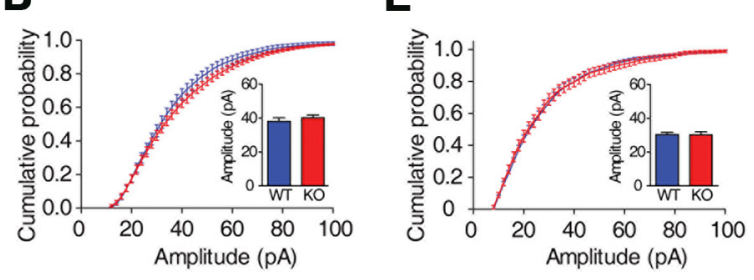

$\mathbf{F}$

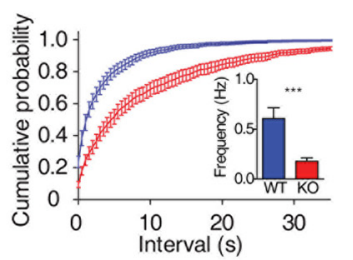

K Paired Pulse Stimulation

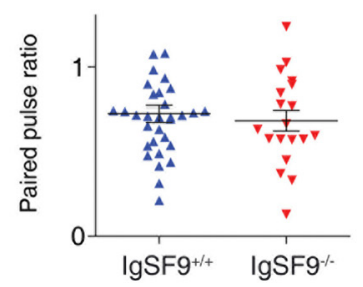

G

H

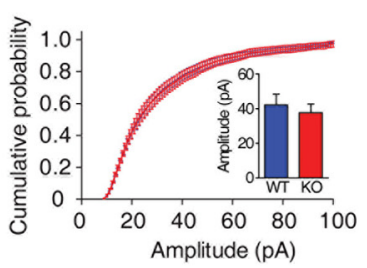

I

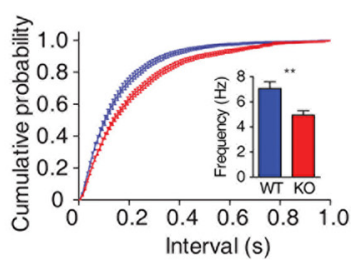

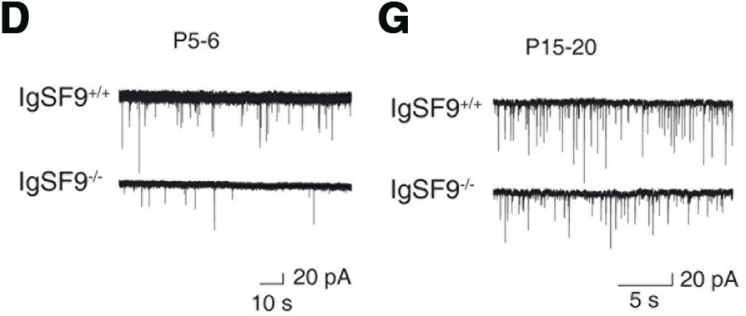

Loss of IgSF9 affects inhibitory synaptic transmission. $\boldsymbol{A}-\boldsymbol{C}$, Sample traces $(\boldsymbol{A})$ and cumulative distributions of ampli作 frequencies $(I)$ of spontaneous IPSCs in pyramidal neurons of P15-P20 hippocampal slices from the indicated mice. J, Sample traces of evoked IPSCs paired pulse stimulation for 40 ms interstimulus interval of P15-P20 mice. $\boldsymbol{K}$, Quantification of PPRs of eIPSCs. Error bars indicate SEM in all graphs. Insets show mean amplitude or frequency.

miniature EPSCs were recorded in juvenile mice (P15-P20; Fig. 2D). In contrast, neither amplitudes nor frequencies of mEPSCs were altered in $I g S F 9^{-1-}$ mice compared with IgSF9 ${ }^{+/+}$littermates $(13.8 \pm 0.7 \mathrm{pA}$ mean amplitude in IgSF9 ${ }^{+/+}$vs $13.2 \pm 0.3 \mathrm{pA}^{2}$ in IgSF9 ${ }^{-/-}$mice; $p=1, \mathrm{~K}-\mathrm{S}$ test; $0.6 \pm 0.1 \mathrm{~Hz}$ mean frequency in $\operatorname{IgSF9}^{+/+}[n=11]$ and $0.5 \pm$ $0.1 \mathrm{~Hz}$ in $\mathrm{IgSF9}^{-1-}$ mice $[n=17] ; p=1$, K-S test; Fig. $\left.2 E, F\right)$. Similar observations were made using younger mice (P7-P8) suggesting comparable number and size of AMPA-R containing synapses $\left(14.3 \pm 3.8 \mathrm{pA}\right.$ mean amplitude in $\operatorname{IgSF9}^{+/+}, n=$ 23 cells, vs $14.0 \pm 0.5 \mathrm{pA}$ in IgSF9 ${ }^{-1-}$ mice, $n=16$ cells, $p=$ 1 , K-S test; $0.4 \pm 0.1 \mathrm{~Hz}$ mean frequency in $\operatorname{IgSF9}^{+/+}$vs $0.4 \pm$ $0.0 \mathrm{~Hz}$ in IgSF9 ${ }^{-1-}$ mice; $p=1$, K-S test; data not shown).

We further tested the presynaptic release machinery by applying two consecutive stimuli with interstimulus intervals of $40 \mathrm{~ms}$ (sample traces in Fig. 2G). The PPR, a sensitive measure of changes in the probability of transmitter release, was unchanged $\left(2.0 \pm 0.1\right.$ in IgSF9 $^{+/+}, n=25$ cells, vs $2.0 \pm 0.1, n=$ 28 cells, in IgSF9 $^{-1-}$ mice; $p>0.05$, Student's $t$ test; Fig. $2 H$ ). 

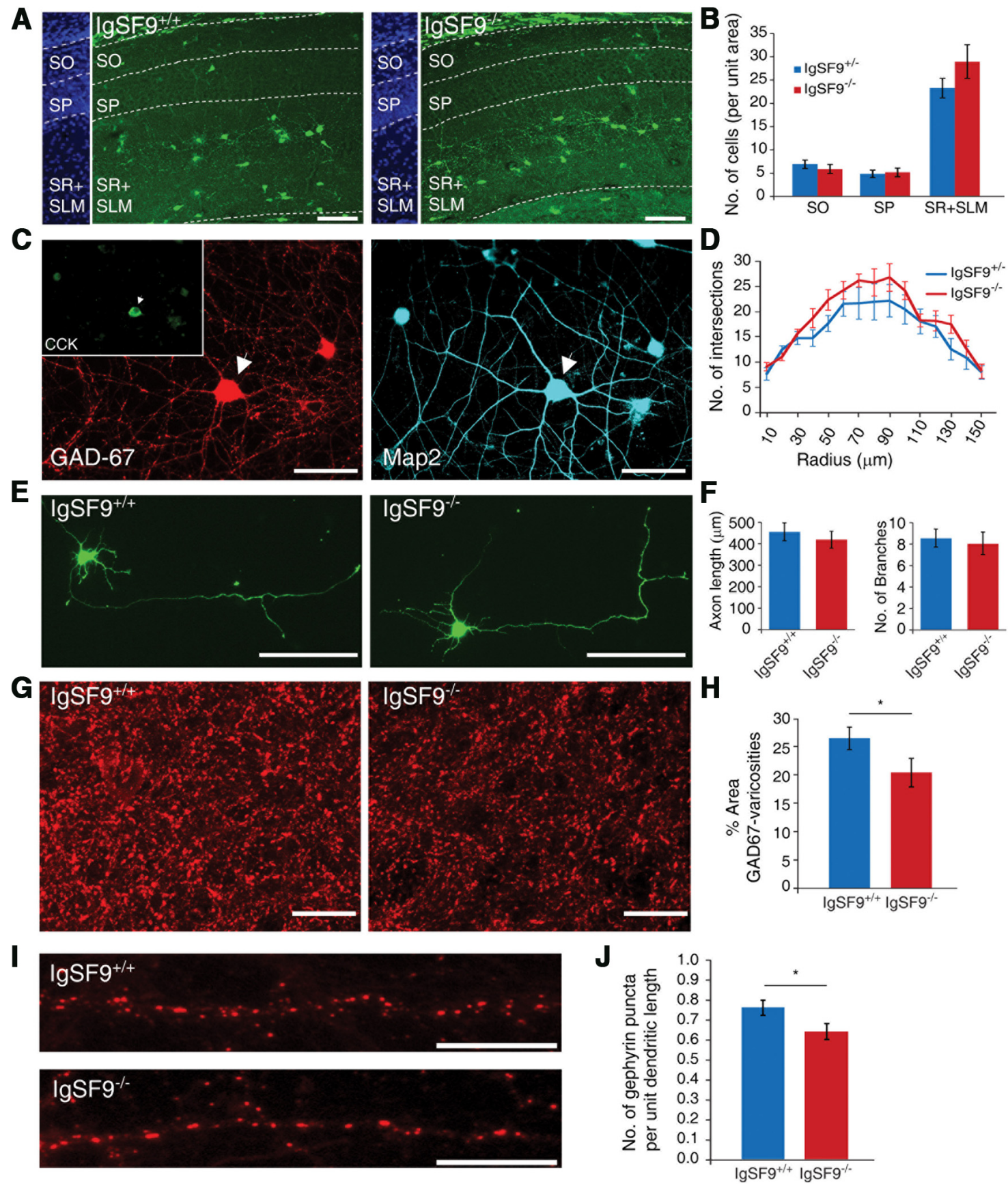

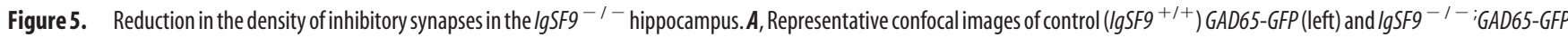
(right) hippocampi showing GAD-65 expressing interneurons (green) adjacent to their respective DAPI-stained nuclei (blue) for layer identification. Stippled lines indicate the borders of the strata. $B$, Quantitative analysis of the distribution of GAD-65 expressing interneurons in stratum oriens (SO), stratum pyramidale (SP), and strata radiatum (SR) + lacunosum-moleculare (SLM) layers in the CA1 region of lgSF9 ${ }^{+/+}$(blue) and lgSF9 ${ }^{-1-}$ (red) hippocampi (600 cells counted for $n=3$ mice per genotype, $p>0.05$, Student's $t$ test). C, Dendritic morphology of a GAD-67-stained interneuron (left) that coexpressed CCK (inset; arrow) assessed by Map2 staining (right) after 14 DIV hippocampal neuronal culture. D, Quantification of dendritic complexity by Sholl analysis (25 neurons from each group, $n=3$ cultures). $\boldsymbol{E}$, Representative images of GAD-67-stained interneurons in control (left) and lgSF9-1- (right) neuronal cultures ( 3 DIV). $\boldsymbol{F}$, Quantification of axonal outgrowth (total length; left) and number of branches (right) of interneurons (30 neurons from each group, $n=3$ cultures, $p>0.2$, Student's $t$ test). $G$, Immunostaining of GAD67 in P20 hippocampus (subiculum) from lgSF9 ${ }^{+/+}$(left) and lgSF9 ${ }^{-1-}$ (right) mice. $\boldsymbol{H}$, Quantification of total area covered by GAD67 ${ }^{+}$clusters per $11000 \mu \mathrm{m}^{2}$ hippocampus (24 images in $n=3$ mice per group; $p<0.05$, Student's $t$ test). $I$, Representative confocal images of dendrites of hippocampal neurons from lgSF9 ${ }^{+/+}$(top) and lgSF9 ${ }^{-I-}$ (bottom) embryos cultured for $15 \mathrm{~d}$ and immunostained for gephyrin to label inhibitory synapses.J, Quantification of the gephyrin-positive puncta density performed on segments of primary and secondary dendrites (on average, $50 \mu \mathrm{m}$ dendrite per neuron, $n=25$ neurons per genotype; $p<0.05$, Student's test). Values represent mean \pm SEM. Scale bars: $A, 100 \mu \mathrm{m} ; C, E, 50 \mu \mathrm{m} ; \boldsymbol{G}, 20 \mu \mathrm{m} ; I, 10 \mu \mathrm{m}$.

\section{Excitatory synapse/spine density is unaltered in $\mathrm{IgSF}^{-1-}$} mice

Spines are actin-rich dendritic protrusions that harbor the majority of excitatory synapses and are highly plastic structures that change size and shape during development and learning pro- cesses. Although an absence of IgSF9 did not affect the function of excitatory synapses, we wondered whether it might influence the density and/or morphology of spines and synapses. We found that the density of spines in the apical dendrites of CA1 pyramidal neurons between P15 and P45 was not different between 
Targeting Strategy

A

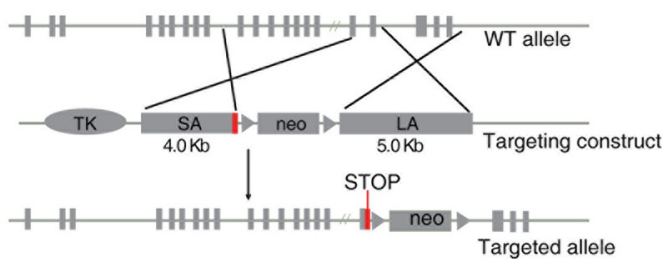

TM
Amino acid sequence: WT ...ILAACL $\triangle C$...ILAACL|MNRRRAARRHRKRLRQ*
B

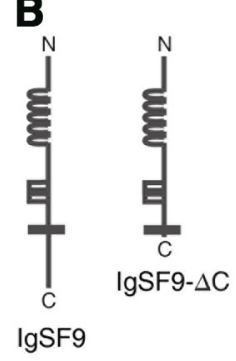

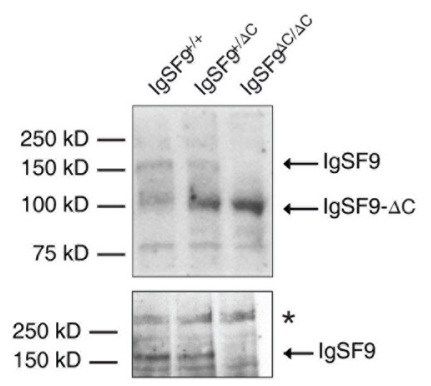

miniature IPSCs
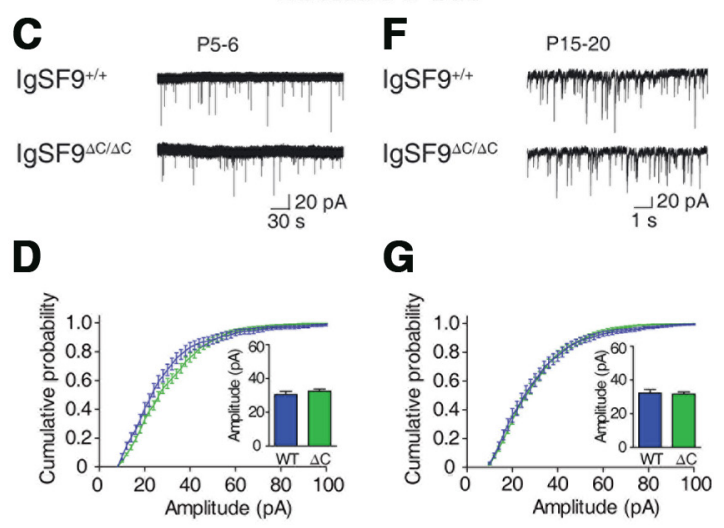

E

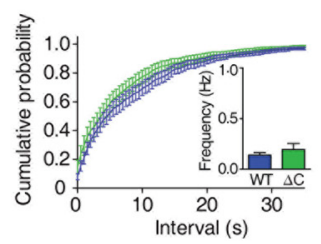

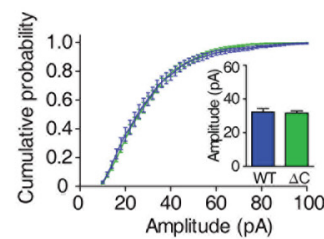

H

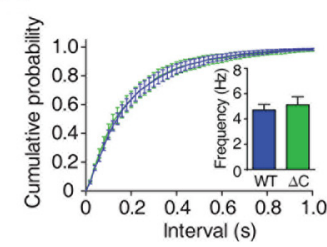

Figure 6. IgSF9- $\Delta$ C lacking the cytoplasmic domain mediates normal inhibitory transmission. $A$, Schematic diagram of the strategy for targeted removal of the cytoplasmic domain of IgSF9 by homologous recombination showing the wild-type (WT) allele, the targeting construct, and the targeted allele. The neomycin resistance cassette is flanked by lox sites (triangles). The amino acid sequence at the border between transmembrane (TM) and juxtamembrane (JUX) regions are shown (asterisk indicates stop codon). TK, Thymidine kinase; SA, short arm; LA, long arm. $B$, Diagram of WT and truncated $(\Delta C)$ lgSF9 protein (Left) and Western blots to confirm the presence of IgSF9- $\Delta$ C protein in the lgSF9 $\Delta C / \Delta$ mice and the loss of intracellular domain using different antibodies raised against the extracellular domain (top) and the intracellular domain (bottom) of IgSF9, respectively. An unspecific band in the lower blot $\left(^{*}\right)$ serves as loading control. In IgSF9 $\Delta C / C_{\text {mice, }}$ neither frequencies nor amplitudes of mIPSCs are altered in P5-P6 and P15-P20 hippocampal CA1 pyramidal neurons. C, $F$, Sample traces of mIPSCS of P5-P6 and P15-P20 mice in control and IgSF9 ${ }^{\Delta C \Delta C}$ slices, respectively. $\boldsymbol{D}, \boldsymbol{E}$, Cumulative distribution plots of the amplitudes $(\boldsymbol{D})$ and frequencies $(\boldsymbol{E})$ of P5-P6 mice. $\boldsymbol{G}, \boldsymbol{H}$, Cumulative distribution plots of the amplitudes $(\boldsymbol{G})$, and frequencies $(\boldsymbol{H})$ of P15-P20 mice. Error bars indicate SEM in all graphs. Insets show mean amplitude or frequency.

IgSF9 $^{-1-}$ mice and control littermates (Fig. $3 A, B$ ). Likewise, spine length and width of the spine heads were comparable in the two genotypes (Fig. $3 C, D$ ). As shown by ultrastructural analysis, the density of excitatory synapses in hippocampal sections was not reduced in $\mathrm{IgSF}^{-1-}$ mice (Fig. 3 E, F). Consistent with these findings, the numbers of excitatory synapses identified by PSD-95 staining in cultured hippocampal neurons were also similar in $\mathrm{IgSF}^{-1}$ mice and cultures from control littermates (Fig. $3 G, H)$. Together these results suggest that IgSF9 is not essential for the development of functional excitatory synapses in the hippocampus.

\section{Reduced inhibitory synaptic transmission in IgSF9 $^{-/-}$ pyramidal neurons}

Since IgSF9 is expressed at inhibitory synaptic sites, we investigated the role of IgSF9 in the function of inhibitory synapses onto pyramidal neurons. Interestingly, we found reduced mIPSC frequencies in cells from P15-P20 IgSF9 ${ }^{-1-}$ slices compared with littermate controls $(7.4 \pm 0.3 \mathrm{~Hz}$ mean frequency in controls, $n=$ 20 cells, vs $6.4 \pm 0.2 \mathrm{~Hz}$ in IgSF9 ${ }^{-1-}$ slices, $n=36$ cells; $p<0.01$, K-S test; Fig. $4 A, C$ ), whereas mIPSC amplitudes were unaffected $(38.1 \pm 2.2 \mathrm{pA}$ mean amplitude in controls, $n=20$ cells, vs $40.2 \pm 1.5 \mathrm{pA}$ in IgSF9 $^{-1}$ slices, $n=36$ cells, $p=1$; Fig. $4 B$ ). Frequencies of mIPSCs were even more reduced in slices of younger (P5-P6) IgSF9 ${ }^{-1-}$ mice compared with littermate controls $(0.6 \pm 0.1 \mathrm{~Hz}$ mean frequency in controls, $n=31$ cells, vs $0.2 \pm 0.0 \mathrm{~Hz}$ in $\mathrm{IgSF9}^{-1-}$ slices, $n=30$ cells, $p<0.001$, K-S test; Fig. $4 D, F)$, correlating with the higher abundance of IgSF9 protein levels (Fig. 1A). Again, mIPSC amplitudes were not altered $(30.5 \pm 1.3 \mathrm{pA}$ mean amplitude in controls, $n=31$ cells, vs $30.3 \pm 1.9 \mathrm{pA}^{\text {in IgSF9 }}{ }^{-1-}$ slices, $n=30$ cells, $p=1$; Fig. $\left.4 E\right)$. To test whether the loss of functional inhibitory synapses was compensated by higher activity, we next recorded sIPSCs. Similar to mIPSCs, sIPSCs had significantly reduced frequencies, whereas the amplitudes were not altered in P15-P20 $\mathrm{IgSF}^{-1-}$ slices (42.2 $\pm 6.2 \mathrm{pA}$ mean amplitude in controls, $n=27$ cells, vs $37.6 \pm 5.0 \mathrm{pA}$ in IgSF9 $^{-1-}$ slices, $n=22$ cells, $p=1 ; 7.1 \pm 0.5 \mathrm{~Hz}$ mean frequency in controls, $n=27$ cells, vs $4.9 \pm 0.3 \mathrm{~Hz}$ in IgSF9 $^{-{ }^{-}}$mice, $n=22$ cells, $p<0.01$, K-S test; Fig. $\left.4 G-I\right)$. The observed reduced frequencies of both mIPSCs and sIPSCs could arise from either an altered presynaptic release property or a reduction in the number of functional synapses. To distinguish between these two possibilities, we tested the probability of transmitter release by the PPR. No difference was observed in presynaptic release at $40 \mathrm{~ms}$ interstimulus interval when comparing the PPR of $\mathrm{IgSF}^{-1-}$ mice with their littermate controls (controls: $0.7 \pm 0.1, n=32$ IgSF9 $^{-\prime-}: 0.7 \pm 0.1, n=19, p>0.05$, Student's $t$ test; Fig. $4 J, K)$. This suggests that the GABAergic presynapse is functionally normal in IgSF9 ${ }^{-1-}$ mice. Together, these results indicate that IgSF9 is required for normal frequency of inhibitory transmission in CA1 pyramidal neurons within the intact circuitry of the hippocampus, possibly by controlling inhibitory synapse numbers.

\section{IgSF9 $^{-/-}$mice have fewer inhibitory synapses}

Reduced frequencies of mIPSCs suggests a loss of GABAergic inhibitory synapses and may result from a decrease in the numbers of interneurons in the hippocampus. To address this question, we crossed GAD65-GFP transgenic mice with IgSF9 $^{-1-}$ mice and counted the numbers of GFP-positive interneurons in different layers of the hippocampus. We detected no differences in the total numbers of interneurons and in the 
A

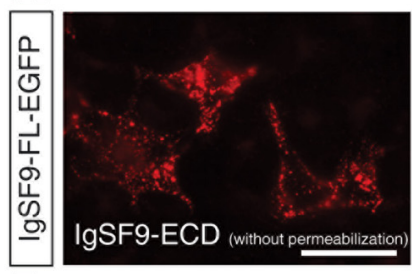

B

D
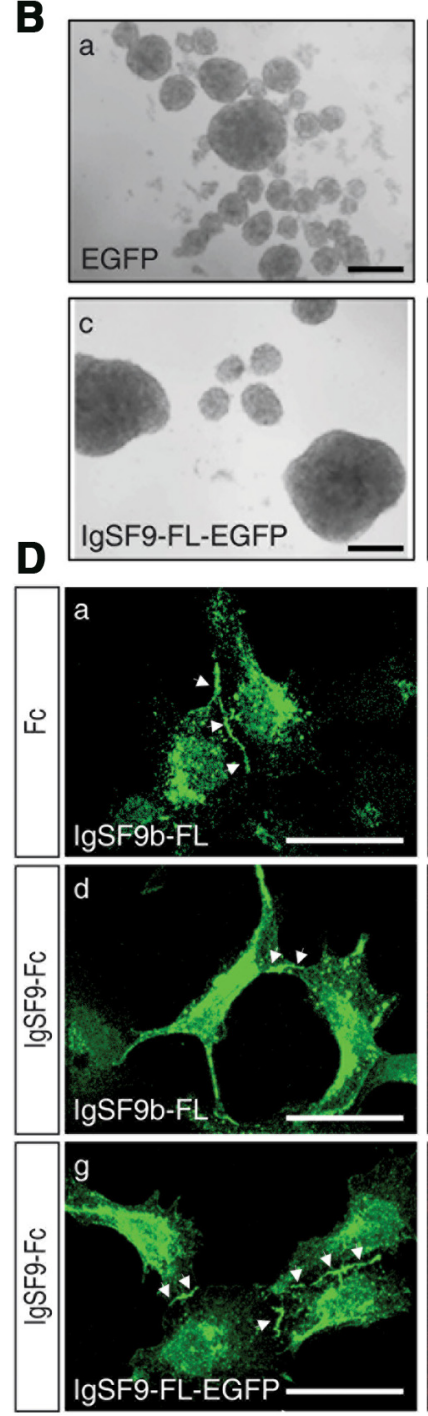
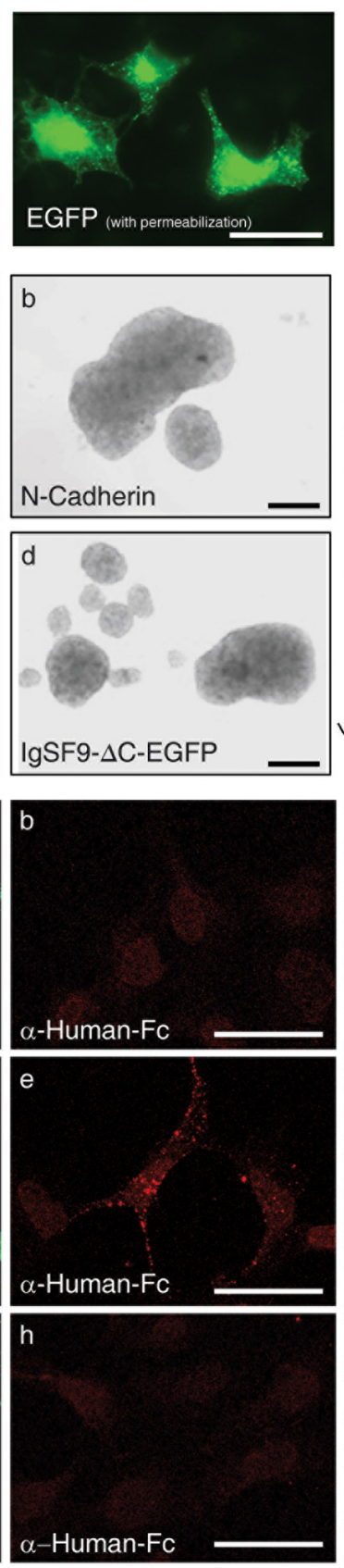

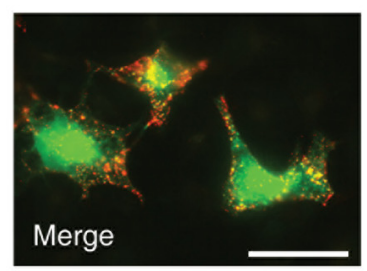

C
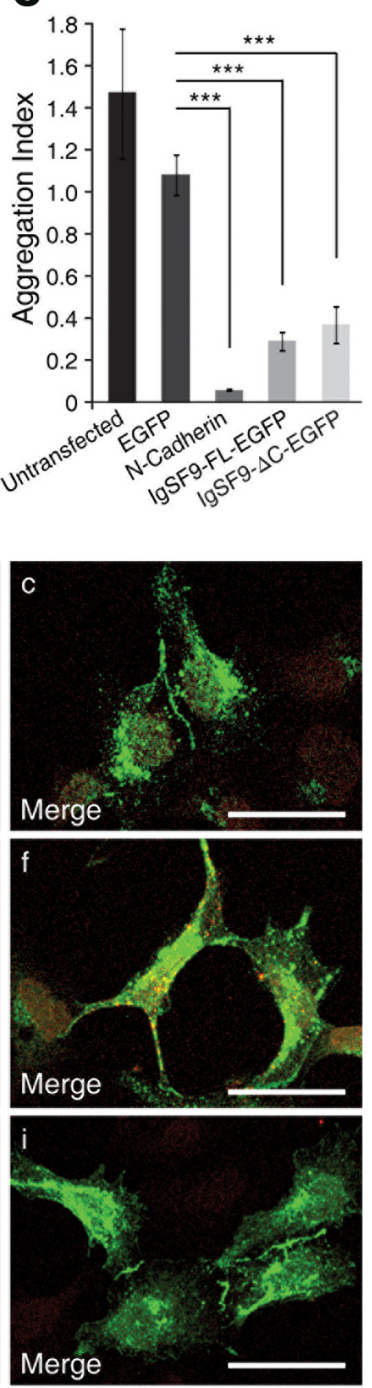

Figure 7. IgSF9 mediates homotypic adhesion but not heterotypic interaction with related IgSF9b. $\boldsymbol{A}$, Surface expression of IgSF9 protein in HEK-293 cells expressing IgSF9-FL-EGFP (full-length-IgSF9 tagged with EGFP). Cells incubated with IgSF9-ECD antiserum (without fixation/permeabilization) label surface lgSF9 (left), whereas staining with anti-GFP antibody postfixation and permeabilization reveals its total expression (middle). $\boldsymbol{B}$, Cell aggregation assay. Representative micrographs showing aggregates formed by transiently transfected HEK-293 cells expressing EGFP (Ba) , N-cadherin (Bb), IgSF9-FL-EGFP (BC), or lgSF9- $\Delta$ C-EGFP ( $\boldsymbol{B d}$; truncated IgSF9 lacking the intracellular domain tagged with EGFP) after $24 \mathrm{~h}$ in culture. Similar to $\mathrm{N}$-cadherin, IgSF9-FL-EGFP and IgSF9- $\Delta$ C-EGFP form larger and fewer cell aggregates compared with the EGFP-expressing cells. C, Aggregation potential of cells expressing different constructs is assessed by calculating Al. Values represent mean $\pm \mathrm{SEM}$ of four individual experiments $(p<0.001$, Student's $t$ test). D, Fc-binding assay. HEK-293 cells expressing IgSF9b-FL (full-length IgSF9b) protein do not bind to Fc alone $(\boldsymbol{D a}-\boldsymbol{D C})$, but show robust homotypic binding upon recombinant IgSF9b-Fctreatment (Dd-Df). In contrast, cells expressing IgSF9-FL-EGFP fail to bind heterotypically to IgSF9b-Fc ( $\mathbf{D g}$-Di). Both IgSF9 and lgSF9b proteins accumulate at the junctions of overexpressing cells, indicating homotypic binding. Scale bars: $\boldsymbol{A}-\boldsymbol{C}, \boldsymbol{D}, 50 \mu \mathrm{m} ; \boldsymbol{B}, 100 \mu \mathrm{m}$.

distribution of interneurons across hippocampal layers between IgSF9 $^{-1-}$ :GAD65-GFP mice and their IgSF9 ${ }^{+/+}$littermates (Fig. $5 A, B)$. Next, we investigated whether dendrite morphology or axonal growth and branching were affected in inhibitory neuron.
Because a large fraction of $\mathrm{CCK}^{+}$interneurons expressed IgSF9 (Fig. 1), we decided to quantify the complexity of their dendritic arbors in vitro. Cultured hippocampal neurons were stained for CCK and GAD67 and the dendritic arbor of double-positive neurons was traced using MAP2 staining followed by Sholl analysis. Dendritic differentiation of these interneurons was comparable in control and $I g S F 9^{-1-}$ cultures (Fig. 5C,D). In addition, axonal outgrowth and branching of GAD $67^{+}$interneurons were not significantly different in the $\mathrm{IgSF}^{-1-}$ neurons compared with wild-type controls (Fig. $5 E, F)$. Finally, we investigated whether inhibitory synapses were reduced in $\mathrm{IgSF}^{-I^{-}}$mice and performed immunohistochemical stainings for the inhibitory presynaptic marker GAD67 on coronal brain sections. There was a significant decrease of $\mathrm{GAD} 7^{+}$varicosities in the subicular stratum radiatum region of IgSF9 ${ }^{-1-}$ mice compared with controls (23\% reduction, $p<0.05$, Student's $t$ test; Fig. 5G,H). We further assessed the density of inhibitory synapses in cultured hippocampal neurons using the numbers of clusters positive for the postsynaptic scaffold protein gephyrin as a readout. By these criteria, the numbers of inhibitory synapses were significantly reduced in IgSF9 $^{-1-}$ mice compared with cultures derived from littermate controls (16\% reduction, $p<0.01$, Student's $t$ test; Fig. $5 I, J)$. These findings provide genetic support for a requirement of IgSF9 in controlling the numbers of inhibitory synapses in hippocampal pyramidal neurons.

\section{Cytoplasmic region of IgSF9 is not required for inhibitory synapse development}

The related IgSF9b protein has recently been suggested to interact with postsynaptic scaffolding proteins in cultured interneurons (Woo et al., 2013). To obtain genetic evidence for a requirement of the cytoplasmic region of IgSF9 for development of inhibitory synapses, we generated knock-in mice expressing a C-terminally truncated isoform of IgSF9 (termed $I g S F 9^{\delta \mathrm{C}}$ mice). Exon 18 encoding the juxtamembrane domain was replaced by a neo cassette in a manner that introduced a stop codon 16 aa C-terminal of the transmembrane domain of IgSF9

(Fig. 6A). The presence of the truncated IgSF9- $\Delta$ C protein (Fig. $6 B$ ) was confirmed by Western blot using an extracellular-domain-specific antibody against IgSF9 (Fig. 6B, top right). IgSF9- $\Delta$ C protein had a similar apparent molecular weight as a slower migrating wild-type IgSF9 species, which may be the result 
A
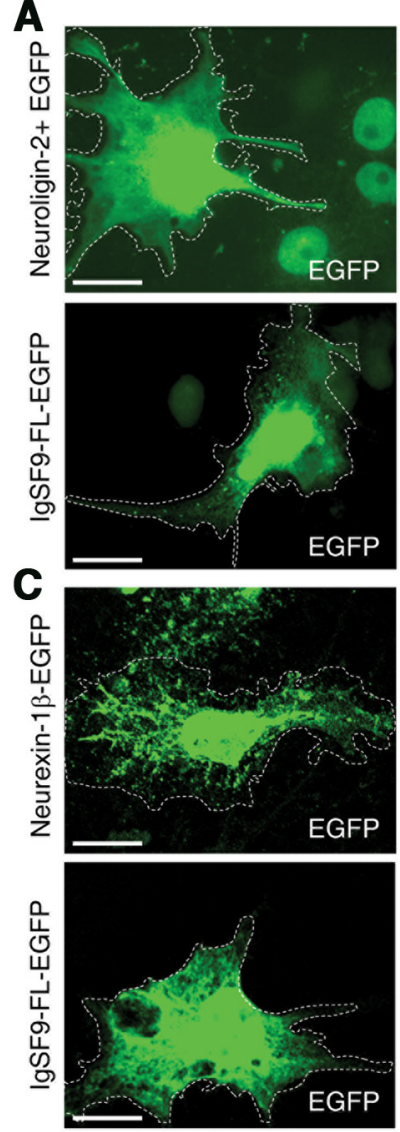
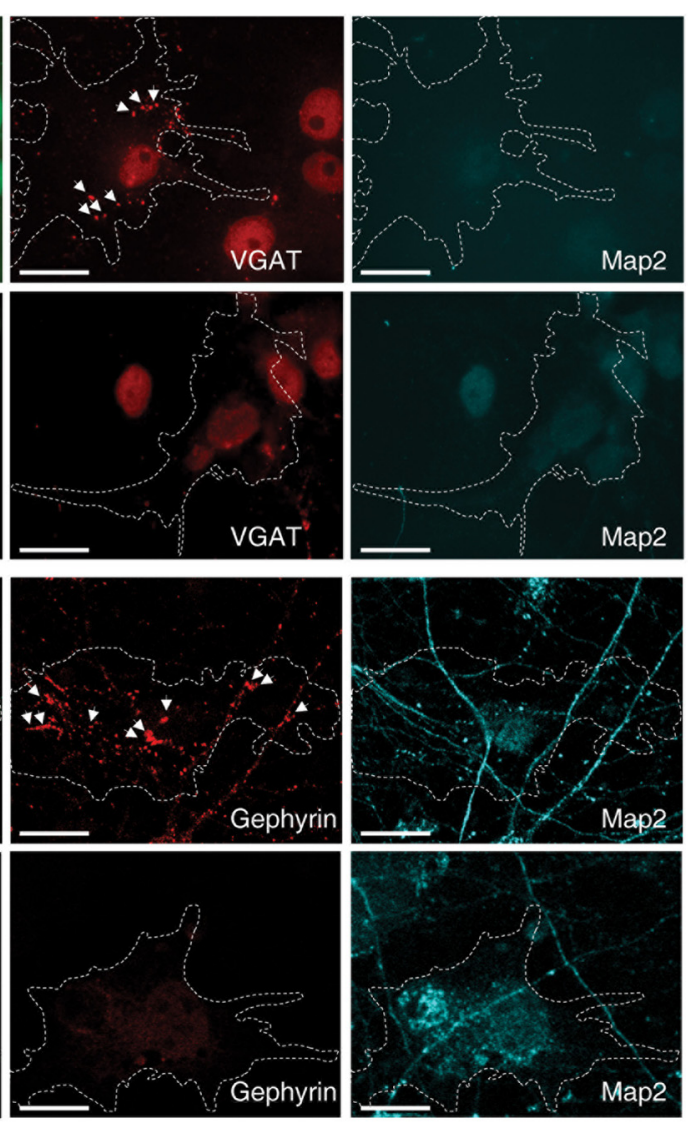
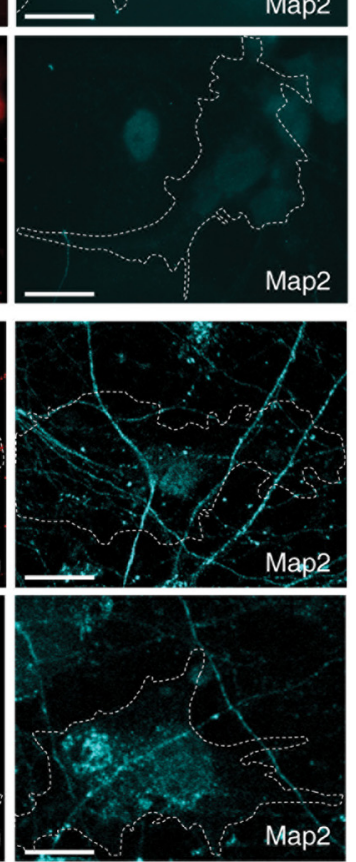

B
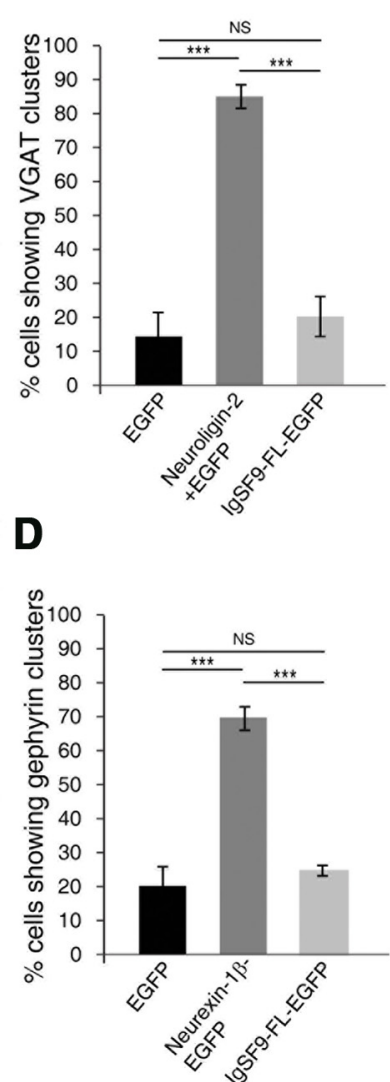

Figure 8. IgSF9 does not induce presynaptic or postsynaptic differentiation of inhibitory synapses. Mixed culture assay to test presynaptic and postsynaptic induction of inhibitory synapses. COS cells expressing Neuroligin-2 $(\boldsymbol{A})$ and neurexin-1 $\beta(\boldsymbol{C})$ or IgSF9-FL-EGFP cocultured with hippocampal neurons and stained with VGAT or gephyrin antibody (red) to identify inhibitory presynaptic and postsynaptic differentiation, respectively. VGAT/gephyrin-positive clusters induced by Neuroligin-2/neurexin-1 $\beta$-expressing cells, respectively, are indicated by arrowheads. Scale bar, $20 \mu \mathrm{m}$. $\boldsymbol{B}$, Quantification of the mixed culture assay showing percentage of transfected COS cells (expressing EGFP, Neuroligin-2, and EGFP or IgSF9-FL-EGFP) that induce VGAT clustering in presynaptic terminals of cocultured hippocampal neurons ( $n=30$ cells). No significant difference was observed between cells expressing EGFP alone (negative control) and lgSF9-FL-EGFP ( $13.7 \pm 7.0 \%$ vs $20.0 \pm 5.8 \%, p>0.05$, Student's t test), whereas Neuroligin-2 expressing cells showed VGAT clustering ( $82.0 \pm 2.6 \% ; p<0.001)$. Only transfected cells (green) that were negative for the dendrite marker Map2 (cyan) were used to quantify the induced semisynapses. D, Quantification showing percentage of transfected COS cells (expressing EGFP, neurexin-1 $\beta$-EGFP, or IgSF9-FL-EGFP) that induce gephyrin clustering in dendrites (identified by Map2 staining) of cocultured hippocampal neurons ( $n=30$ cells). No significant difference was observed between cells expressing EGFP alone and IgSF9-FL-EGFP (19.7 $\pm 6.0 \%$ vs $25.1 \pm 1.2 \%, p>0.05$, Student's $t$ test), whereas neurexin- $1 \beta$-expressing cells showed gephyrin clustering $(69.1 .0 \pm 3.2 \%, p<0.001$, Student's $t$ test). Values represent mean \pm SEM of three individual experiments.

of alternative splicing (Shi et al., 2004b) or ectodomain shedding. Loss of the intracellular domain in the IgSF9- $\Delta$ C protein was verified using an antibody against the C-terminal domain of IgSF9 (Fig. $6 B$, bottom right). Homozygous $\operatorname{IgSF}^{\Delta \mathrm{C} / \Delta \mathrm{C}}$ mice were born at the Mendelian ratio and exhibited no gross morphological defects in the brain (data not shown). Unexpectedly, the phenotypes observed in $I_{g S F 9}{ }^{-1-}$ mice were not present in IgSF9 ${ }^{\Delta \mathrm{C} / \Delta \mathrm{C}}$ mice. The amplitudes and frequencies of mIPSCs of both young (P5-P6) and juvenile (P15-P20) mice were unaltered in $\operatorname{IgSF}^{\Delta \mathrm{C} / \Delta \mathrm{C}}$ slices compared with control littermates (P5-P6, $30.5 \pm 1.9$ pA mean amplitude in controls, $n=12$ cells, $32.5 \pm 1.3$ pA in $I g S F 9^{\Delta \mathrm{C} / \Delta \mathrm{C}}, n=14$ cells, $p=$ $1 ; 0.1 \pm 0.0 \mathrm{~Hz}$ mean frequency in controls, $n=12$ cells, $0.2 \pm 0.1 \mathrm{~Hz}$ in IgSF9 ${ }^{\Delta \mathrm{C} / \Delta \mathrm{C}}$ mice, $n=14$ cells, $p=1$, K-S test; P15-P20, $32.3 \pm$ $2.1 \mathrm{pA}$ mean amplitude in controls, $n=11$ cells, $31.7 \pm 1.3 \mathrm{pA}$ in IgSF9 ${ }^{\Delta \mathrm{C} / \Delta \mathrm{C}}, n=11$ cells, $p=1 ; 4.7 \pm 0.4 \mathrm{~Hz}$ mean frequency in controls, $n=11$ cells, $5.1 \pm 0.6 \mathrm{~Hz}$ in $I g S F 9^{\Delta \mathrm{C} / \Delta \mathrm{C}}$ mice, $n=11$ cells, $p=1, \mathrm{~K}-\mathrm{S}$ test; Fig. $6 \mathrm{C}-H$ ). In addition, amplitudes and frequencies of sIPSCs were unaffected in the IgSF9 ${ }^{\Delta \mathrm{C} / \Delta \mathrm{C}}$ slices (data not shown). These findings provide genetic evidence that the intracellular domain of IgSF9 is dispensable for regulating the frequency of inhibitory synaptic transmission in hippocampal pyramidal neurons.
IgSF9 mediates homotypic adhesion but is not sufficient to induce inhibitory synapse formation

To begin addressing the mechanism underlying IgSF9 ectodomainmediated regulation of inhibitory synapse numbers, we investigated whether IgSF9 could mediate homophilic adhesion, a property that has previously been attributed to Drosophila IgSF9 (Ferguson et al., 2009) and mammalian IgSF9b (Woo et al., 2013). We expressed full-length IgSF9 fused to EGFP, IgSF9- $\Delta$ C fused to EGFP, EGFP alone, or, as positive control, the cell adhesion molecule $\mathrm{N}$-cadherin in HEK293 cells and confirmed that these proteins were expressed on the surface (Fig. $7 \mathrm{~A}$ and data not shown). We then let the cells form aggregates on a gyratory shaker for $24 \mathrm{~h}$. Cell aggregates formed under these conditions were quantified by calculating the aggregation index $(\mathrm{AI}=$ the total number of aggregates/size of the biggest aggregate) such that lower AI indicates higher aggregation propensity. In the presence of full-length IgSF9 and IgSF9- $\Delta$ C, cells formed significantly larger and fewer aggregates compared with cells expressing EGFP alone (or nontransfected cells; Fig. $7 \mathrm{~B}, \mathrm{C}$ ), suggesting that IgSF9 mediates homophilic adhesion. These results also indicated that the cytoplasmic domain of IgSF9 is dispensable for this activity. 
A

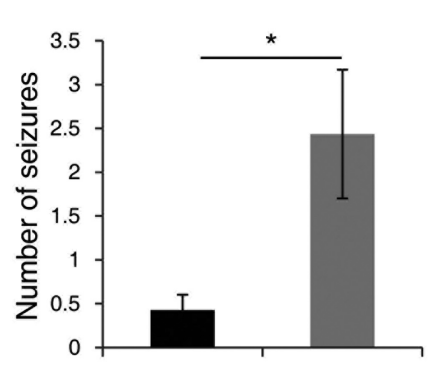

C
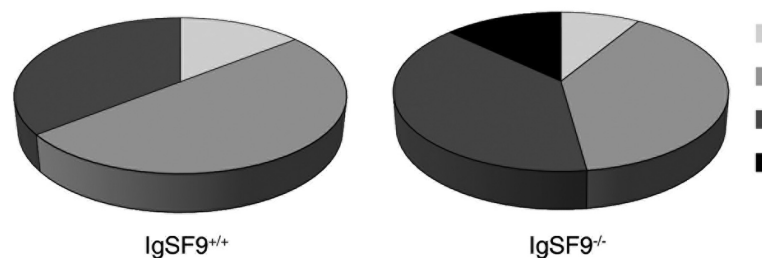

non-seizure

myoclonus

- seizure

generalized tonic-clonic seizure

IgSF9

Figure 9. IgSF9 ${ }^{-1-}$ mice show increased susceptibility for PTZ-induced seizures. Mice were given a single injection of PTZ (45 $\mathrm{mg} / \mathrm{kg}$, i.p.) and behavior was assessed for $30 \mathrm{~min}$ to record extent of seizures and latencies in $/ g S F 9^{+/+}(n=14)$ and lgSF9 ${ }^{-1-}$ mice $(n=23)$. $\boldsymbol{A}$, Number of seizures per mouse (mean of all animals tested; $p<0.05$, Student's $t$ test). $\boldsymbol{B}$, Latencies are defined as the time (in seconds) between the injection and the onset of the behavioral trait such as grooming, flat position, twitching, and seizure. IgSF9 ${ }^{-1-}$ mice show reduced latency for attaining seizure state ( $p<0.05$, Student's $t$ test). C, Distribution of the maximum reaction reached during the observation period shows increased vulnerability of IgSF9- - mice to PTZ, which exhibited more severe tonic-clonic seizures that were absent in IgSF9 ${ }^{+/+}$mice. Values represent mean \pm SEM.

Heterophilic aggregate formation between cells expressing IgSF9 and the related IgSF9b was not tested because soluble IgSF9b-Fc bound to itself, but not to IgSF9 (Fig. 7D). We considered this sufficient evidence to suggest that IgSF9b should be unable to compensate for the lack of IgSF9. Synaptic cell adhesion molecules such as neuroligins and SynCAMs function as synaptic organizers in mixed coculture assays (Biederer and Scheiffele, 2007, Scheiffele et al., 2000). Given that IgSF9 regulates the numbers of inhibitory synapses in vivo, we tested the ability of IgSF9 to induce inhibitory synapse formation in such a mixed culture assay. COS cells overexpressing Neuroligin-2, when seeded on top of hippocampal neurons that had been cultured for $14 \mathrm{~d}$ (14 DIV), induced inhibitory presynaptic differentiation as revealed by staining with the presynaptic marker vesicular GABA transporter (VGAT; Fig. 8A, B). In contrast, COS cells overexpressing fulllength IgSF9-FL-EGFP failed to induce VGAT or synapsin-1 clustering (Fig. 8A,B and data not shown). IgSF9 also failed to induce inhibitory postsynaptic differentiation as revealed by staining with the postsynaptic marker gephyrin (Fig. 8C,D), suggesting that IgSF9 is not sufficient to induce synaptic differentiation in cultured hippocampal neurons. Together with the loss of inhibitory synapses in $\mathrm{IgSF9}^{-1-}$ mice, these findings indicate that either IgSF9 functions in conjunction with other synaptic proteins to establish new synapses or it is required to stabilize or maintain the already existing synapses.

\section{Mice lacking IgSF9 are more susceptible to PTZ- induced seizures}

The presence of fewer inhibitory synapses in the hippocampus may render $I g S F 9^{-1-}$ mice more prone to seizures. Because IgSF9 $^{-/-}$mice do not show spontaneous seizures, we challenged them with the convulsant drug PTZ, a GABA antagonist that has previously been shown to induce seizures in mice (Weiergraber et al., 2006). We tested 3-week-old IgSF9 $^{-1-}$ mice, which showed significantly reduced frequencies of mIPSCs in hippocampal slices (Fig. 4). A single intraperitoneal injection of $45 \mathrm{mg} / \mathrm{kg}$ PTZ induced significantly more seizures in $\operatorname{IgSF}^{-1-}$ mice compared with their control littermates (6-fold increase, $p<0.05$, Student's $t$ test; Fig. 9A). The latency time required for mice to develop a seizure was reduced by $36 \%$ in IgSF9 $^{-1-}$ mice compared with their control littermates $(p<0.05$, Student's $t$ test; Fig. 9B). In addition, more IgSF9 ${ }^{-1-}$ mice developed seizures compared with the control group (52\% vs $36 \%$, respectively). When the maximum reaction of each animal was recorded, the PTZ-induced seizures in $\mathrm{IgSF}^{-1-}$ mice were more severe than in controls: three of 23 mutant mice had generalized tonicclonic seizures compared with none of the control mice (Fig. 9C). Therefore, IgSF9 $^{-1-}$ mice exhibited increased susceptibility to PTZ-induced seizures, possibly as a consequence of reduced synaptic inhibition.

\section{Discussion}

Here, we have identified the CAM IgSF9 as a critical regulator of inhibitory synapse development in the mouse hippocampus. Genetic inactivation of the IgSF9 gene resulted in fewer functional inhibitory synapses, whereas the strength of the remaining synapses was unaltered. Decreased synaptic inhibition in $\mathrm{IgSF}^{-1-}$ mice correlated with enhanced seizure susceptibility, suggesting a role for IgSF9 in establishing excitation/inhibition balance. Mechanistically, the extracellular domain of IgSF9 was sufficient for its function in inhibitory synapse development and IgSF9-mediated homotypic cell aggregation, consistent with a model that IgSF9 acts as a CAM to support synapse formation and/or maintenance.

\section{IgSF9 family proteins and inhibitory synapse development}

The effects on inhibitory synapse development in the CA1 region of the hippocampus of IgSF9 ${ }^{-1-}$ mice were quite specific. The numbers of interneurons remained unchanged, but the numbers of functional inhibitory synapses were reduced by $\sim 20 \%$ depending on the assay that was used. The strength of the remaining synapses and presynaptic neurotransmitter release seemed unaltered. Moreover, excitatory synapse development was completely normal. Interestingly, the related IgSF9b CAM was recently shown to be necessary for inhibitory synapse formation onto interneurons in cultured hippocampal neurons (Woo et al., 2013). IgSF9b shRNA knock down led to a small but significant decrease in the number of inhibitory synapses and had no effect on excitatory synapse number in interneurons. IgSF9b expression in pyramidal neurons was relatively weak and reducing its expression further did not affect inhibitory synapse number. Although the in vivo functions of IgSF9b remain to be investigated, our work, together with the report on IgSF9b, establishes the IgSF9 family proteins as regulators of inhibitory synapse development. To the best of our knowledge, this is the first example of a small family of CAMs dedicated to inhibitory synapse development. Among the neuroligins, only neuroligin 2 promotes inhibitory synapse formation; other members of the family promote excitatory synapse formation (Chih et al., 2005, Chubykin et al., 
2007, Graf et al., 2004, Levinson et al., 2005, Varoqueaux et al., 2006). In the Slitrk family, only Slitrk3 specifically controls inhibitory synapse development (Takahashi et al., 2012). The LAR receptor protein tyrosine phosphatase family members are involved both in excitatory and inhibitory synapse development (Yim et al., 2013). Interestingly, both IgSF9 and IgSF9b are insufficient to induce synapse formation on their own, but their loss results in reduced numbers of inhibitory synapses (Woo et al., 2013). It is therefore conceivable that these proteins collaborate with other synaptic proteins to establish new synapses. Alternatively, IgSF9 and IgSF9b might function to stabilize or maintain inhibitory synapses. CAMs such as SynCAM1 (Robbins et al., 2010) and SALM2 (Ko et al., 2006) have been shown to maintain excitatory synapses, but, to the best of our knowledge, there has been no report of molecules stabilizing inhibitory synapses.

\section{How does IgSF9 promote synaptic inhibition?}

Mechanistically, IgSF9 and IgSF9b share similarities, but also seem to have distinct properties. Both CAMs mediate homophilic adhesion or homotypic aggregation and are not sufficient to induce synapse formation. Both proteins are localized at inhibitory synapses. Interestingly, IgSF9b was shown to act on the postsynaptic side of inhibitory synapses onto interneurons (Woo et al., 2013), whereas our study suggests that IgSF9 is enriched on the presynaptic side and is required for inhibitory synapse onto pyramidal neurons. Whether IgSF9 and IgSF9b are necessary in either the presynaptic or postsynaptic compartment in vivo will require conditional knock-out mice and is a direction of future studies.

The most striking difference between IgSF9 and IgSF9b was the role of their respective intracellular domains (ICDs). The ICD of IgSF9b was shown to interact with Neuroligin-2 by way of the scaffolding protein S-SCAM and it was suggested, although not formally shown, that this interaction is necessary for synapse formation (Woo et al., 2013). In contrast, our results obtained with the IgSF $9^{\Delta \mathrm{C} / \Delta \mathrm{C}}$ mice indicate that the essential parts of IgSF9 are ectomembrane and transmembrane domains. The IgSF9 $\Delta$ C protein, lacking the entire ICD, was able to promote normal inhibitory synapse development. How can these discrepancies be reconciled? First, the discrepancies may be mostly technical and reflect the differences in approaches used and the inherent limitations of each approach. Whereas IgSF9b was studied using RNAi knock down in cultured neurons, which causes rather rapid, albeit incomplete loss-of-function, IgSF9 was studied in knock-out mice in which the manipulation was present throughout development. Moreover, synapses that form between cultured neurons are easily accessible, but may not faithfully reflect the organization of synapses formed in vivo.

Second, and perhaps more interestingly, IgSF9 and IgSF9b may operate under different modes of actions. Sequence similarities between the ECDs of IgSF9 and IgSF9b are much higher than between their ICDs (Hansen and Walmod, 2013), suggesting less evolutionarily conserved functions for the ICD. Therefore, it is possible that the IgSF9b ICD is essential for its role at inhibitory synapses in interneurons, whereas IgSF9 relies more on its ECD to regulate inhibitory synapses in pyramidal neurons.

Third, both proteins may operate with similar mechanisms and the importance of the ICD is context dependent. Support for such a model comes from studies on Turtle, the fly homolog of IgSF9. The Turtle ICD was dispensable for its role in dendrite branching of sensory neurons, but required to fully rescue viability in tutl mutants, suggesting that the importance of the Turtle ICD was context dependent (Long et al., 2009). It is therefore possible that, as more functions for the mammalian IgSF9 family proteins are discovered, we may find context dependent functions as signaling receptors or CAMs that do or do not require the ICD, respectively. Such a model would not be without precedents. A variant of Neuroligin-1 lacking its ICD was sufficient to provide temporary synapse stabilization, but not maturation, indicating somewhat separate roles for ECD and ICD interactions (Chen et al., 2010). Overexpression of neuroligins and LRRTMs in cultured neurons routinely increases synapse numbers. The ICD of LRRTM2 was not required for increasing synapse density and recruiting and/or stabilizing AMPARs (Ko et al., 2011, SolerLlavina et al., 2011). Because synaptogenic CAMs comprise large trans-synaptic protein interaction networks, there are plenty of possibilities for the IgSF9 ECD to interact with other proteins and indirectly affect presynaptic and/or postsynaptic differentiation without the need for ICD interactions.

\section{IgSF9 regulates seizure susceptibility}

IgSF9 was previously suggested as a candidate to play a role in seizure susceptibility based on open reading frame single nucleotide polymorphisms resulting in amino acid substitutions in mice (Ferraro et al., 2004, Hansen and Walmod, 2013). Interestingly, we found that $\mathrm{IgSF}^{-1-}$ mice displayed enhanced susceptibility to generalized PTZ-induced seizures. We speculate that partial loss of functional inhibitory synapses in $\mathrm{IgSF9}^{-/-}$mice creates an excitatory/inhibitory imbalance at the cellular and circuit level in the hippocampus (and perhaps elsewhere in the brain) and may contribute to seizure susceptibility. These results are consistent with reports on Slitrk3 $3^{-1-}$ mice, which exhibited decreases in inhibitory, but not excitatory, synapse numbers and function in hippocampal CA1 neurons and displayed increased seizure susceptibility (to PTZ) and spontaneous epileptiform activity (Takahashi et al., 2012). In general, counterbalancing the excitatory drive and inhibitory input greatly extends the dynamic range of excitation, allowing a fine and rapid control over the amount of depolarization. Even small deviation might tip this fine balance over and cause spontaneous discharges resulting in seizures or higher seizure susceptibility. In addition to seizure susceptibility, IgSF9 ${ }^{-1-}$ mice displayed mild impairments in other cognitive tests such as novel object recognition (data not shown); however, the underlying cellular and molecular mechanisms remain to be investigated. Based on our current knowledge on the related IgSF9b CAM, which promotes inhibitory synapses onto GABAergic interneurons, the prediction would be that IgSF9 $b^{-1-}$ mice would not be susceptible to seizures. IgSF9 $b^{-1-}$ mice may display increased GABAergic transmission to pyramidal neurons and thereby reduced overall circuit excitation.

Whatever the precise mechanism of action will turn out to be, IgSF9 family proteins represent novel regulators of synaptic inhibition. The work presented here sets the stage for future directions using more sophisticated genetics and analysis of network activities and for explorations into the drugability of these proteins for the treatment of neurological and psychiatric diseases.

\section{References}

Al-Anzi B, Wyman RJ (2009) The Drosophila immunoglobulin gene turtle encodes guidance molecules involved in axon pathfinding. Neural Dev 4:31. CrossRef Medline

Biederer T, Scheiffele P (2007) Mixed-culture assays for analyzing neuronal synapse formation. Nat Protoc 2:670-676. CrossRef Medline

Bodily KD, Morrison CM, Renden RB, Broadie K (2001) A novel member of the Ig superfamily, turtle, is a CNS-specific protein required for coordinated motor control. J Neurosci 21:3113-3125. Medline

Chen SX, Tari PK, She K, Haas K (2010) Neurexin-neuroligin cell adhesion complexes contribute to synaptotropic dendritogenesis via growth stabilization mechanisms in vivo. Neuron 67:967-983. CrossRef Medline 
Chih B, Engelman H, Scheiffele P (2005) Control of excitatory and inhibitory synapse formation by neuroligins. Science 307:1324-1328. CrossRef Medline

Chubykin AA, Atasoy D, Etherton MR, Brose N, Kavalali ET, Gibson JR, Südhof TC (2007) Activity-dependent validation of excitatory versus inhibitory synapses by neuroligin-1 versus neuroligin-2. Neuron 54:919931. CrossRef Medline

Dalva MB, McClelland AC, Kayser MS (2007) Cell adhesion molecules: signalling functions at the synapse. Nat Rev Neurosci 8:206-220. CrossRef Medline

de Wit J, Hong W, Luo L, Ghosh A (2011) Role of leucine-rich repeat proteins in the development and function of neural circuits. Annu Rev Cell Dev Biol 27:697-729. CrossRef Medline

Doudney K, Murdoch JN, Braybrook C, Paternotte C, Bentley L, Copp AJ, Stanier P (2002) Cloning and characterization of Igsf9 in mouse and human: a new member of the immunoglobulin superfamily expressed in the developing nervous system. Genomics 79:663-670. CrossRef Medline

Fazzari P, Paternain AV, Valiente M, Pla R, Luján R, Lloyd K, Lerma J, Marín O, Rico B (2010) Control of cortical GABA circuitry development by Nrg1 and ErbB4 signalling. Nature 464:1376-1380. CrossRef Medline

Feng G, Mellor RH, Bernstein M, Keller-Peck C, Nguyen QT, Wallace M, Nerbonne JM, Lichtman JW, Sanes JR (2000) Imaging neuronal subsets in transgenic mice expressing multiple spectral variants of GFP. Neuron 28:41-51. CrossRef Medline

Ferguson K, Long H, Cameron S, Chang WT, Rao Y (2009) The conserved Ig superfamily member Turtle mediates axonal tiling in Drosophila. J Neurosci 29: 14151-14159. CrossRef Medline

Ferraro TN, Golden GT, Smith GG, Martin JF, Lohoff FW, Gieringer TA, Zamboni D, Schwebel CL, Press DM, Kratzer SO, Zhao H, Berrettini WH, Buono RJ (2004) Fine mapping of a seizure susceptibility locus on mouse Chromosome 1: nomination of Kcnj10 as a causative gene. Mamm Genome 15:239-251. CrossRef Medline

Graf ER, Zhang X, Jin SX, Linhoff MW, Craig AM (2004) Neurexins induce differentiation of GABA and glutamate postsynaptic specializations via neuroligins. Cell 119:1013-1026. CrossRef Medline

Hansen M, Walmod PS (2013) IGSF9 family proteins. Neurochem Res 38: 1236-1251. CrossRef Medline

Karaulanov EE, Böttcher RT, Niehrs C (2006) A role for fibronectinleucine-rich transmembrane cell-surface proteins in homotypic cell adhesion. EMBO Rep 7:283-290. CrossRef Medline

Ko J, Kim S, Chung HS, Kim K, Han K, Kim H, Jun H, Kaang BK, Kim E (2006) SALM synaptic cell adhesion-like molecules regulate the differentiation of excitatory synapses. Neuron 50:233-245. CrossRef Medline

Ko J, Soler-Llavina GJ, Fuccillo MV, Malenka RC, Südhof TC (2011) Neuroligins/LRRTMs prevent activity- and $\mathrm{Ca}^{2+} /$ calmodulin-dependent synapse elimination in cultured neurons. J Cell Biol 194:323-334. CrossRef Medline

Krueger DD, Tuffy LP, Papadopoulos T, Brose N (2012) The role of neurexins and neuroligins in the formation, maturation, and function of vertebrate synapses. Curr Opin Neurobiol 22:412-422. CrossRef Medline

Levinson JN, Chéry N, Huang K, Wong TP, Gerrow K, Kang R, Prange O, Wang YT, El-Husseini A (2005) Neuroligins mediate excitatory and inhibitory synapse formation: involvement of PSD-95 and neurexin-1beta in neuroligin-induced synaptic specificity. J Biol Chem 280:17312-17319. CrossRef Medline

Lin Y, Bloodgood BL, Hauser JL, Lapan AD, Koon AC, Kim TK, Hu LS, Malik AN, Greenberg ME (2008) Activity-dependent regulation of inhibitory synapse development by Npas4. Nature 455:1198-1204. CrossRef Medline

Long H, Ou Y, Rao Y, van Meyel DJ (2009) Dendrite branching and selfavoidance are controlled by Turtle, a conserved IgSF protein in Drosophila. Development 136:3475-3484. CrossRef Medline

L’opez-Bendito G, Sturgess K, Erdélyi F, Szabó G, Molnár Z, Paulsen O (2004)
Preferential origin and layer destination of GAD65-GFP cortical interneurons. Cereb Cortex 14:1122-1133. CrossRef Medline

Mishra A, Knerr B, Paixão S, Kramer ER, Klein R (2008) The protein dendrite arborization and synapse maturation 1 (Dasm-1) is dispensable for dendrite arborization. Mol Cell Biol 28:2782-2791. CrossRef Medline

Paluszkiewicz SM, Martin BS, Huntsman MM (2011) Fragile X syndrome: the GABAergic system and circuit dysfunction. Dev Neurosci 33:349364. CrossRef Medline

Poulopoulos A, Aramuni G, Meyer G, Soykan T, Hoon M, Papadopoulos T, Zhang M, Paarmann I, Fuchs C, Harvey K, Jedlicka P, Schwarzacher SW, Betz H, Harvey RJ, Brose N, Zhang W, Varoqueaux F (2009) Neuroligin 2 drives postsynaptic assembly at perisomatic inhibitory synapses through gephyrin and collybistin. Neuron 63:628-642. CrossRef Medline

Robbins EM, Krupp AJ, Perez de Arce K, Ghosh AK, Fogel AI, Boucard A, Südhof TC, Stein V, Biederer T (2010) SynCAM 1 adhesion dynamically regulates synapse number and impacts plasticity and learning. Neuron 68:894-906. CrossRef Medline

Scheiffele P, Fan J, Choih J, Fetter R, Serafini T (2000) Neuroligin expressed in nonneuronal cells triggers presynaptic development in contacting axons. Cell 101:657-669. CrossRef Medline

Shi SH, Cheng T, Jan LY, Jan YN (2004a) The immunoglobulin family member dendrite arborization and synapse maturation 1 (Dasm1) controls excitatory synapse maturation. Proc Natl Acad Sci U S A 101:1334613351. CrossRef Medline

Shi SH, Cox DN, Wang D, Jan LY, Jan YN (2004b) Control of dendrite arborization by an Ig family member, dendrite arborization and synapse maturation 1 (Dasm1). Proc Natl Acad Sci U S A 101:13341-13345. CrossRef Medline

Siddiqui TJ, Craig AM (2011) Synaptic organizing complexes. Curr Opin Neurobiol 21:132-143. CrossRef Medline

Soler-Llavina GJ, Fuccillo MV, Ko J, Südhof TC, Malenka RC (2011) The neurexin ligands, neuroligins and leucine-rich repeat transmembrane proteins, perform convergent and divergent synaptic functions in vivo. Proc Natl Acad Sci U S A 108:16502-16509. CrossRef Medline

Takahashi H, Katayama K, Sohya K, Miyamoto H, Prasad T, Matsumoto Y, Ota M, Yasuda H, Tsumoto T, Aruga J, Craig AM (2012) Selective control of inhibitory synapse development by Slitrk3-PTPdelta trans-synaptic interaction. Nat Neurosci 15: 389-398:S1-S2. CrossRef Medline

Ting JT, Peça J, Feng G (2012) Functional consequences of mutations in postsynaptic scaffolding proteins and relevance to psychiatric disorders. Annu Rev Neurosci 35:49-71. CrossRef Medline

Varoqueaux F, Aramuni G, Rawson RL, Mohrmann R, Missler M, Gottmann K, Zhang W, Südhof TC, Brose N (2006) Neuroligins determine synapse maturation and function. Neuron 51:741-754. CrossRef Medline

Vullhorst D, Neddens J, Karavanova I, Tricoire L, Petralia RS, McBain CJ, Buonanno A (2009) Selective expression of ErbB4 in interneurons, but not pyramidal cells, of the rodent hippocampus. J Neurosci 29:1225512264. CrossRef Medline

Weiergräber M, Henry M, Krieger A, Kamp M, Radhakrishnan K, Hescheler J, Schneider T (2006) Altered seizure susceptibility in mice lacking the $\mathrm{Ca}(v) 2.3 \mathrm{E}$-type $\mathrm{Ca}^{2+}$ channel. Epilepsia 47:839-850. CrossRef Medline

Williams ME, Wilke SA, Daggett A, Davis E, Otto S, Ravi D, Ripley B, Bushong EA, Ellisman MH, Klein G, Ghosh A (2011) Cadherin-9 regulates synapse-specific differentiation in the developing hippocampus. Neuron 71:640-655. CrossRef Medline

Woo J, Kwon SK, Nam J, Choi S, Takahashi H, Krueger D, Park J, Lee Y, Bae JY, Lee D, Ko J, Kim H, Kim MH, Bae YC, Chang S, Craig AM, Kim E (2013) The adhesion protein IgSF9b is coupled to neuroligin 2 via S-SCAM to promote inhibitory synapse development. J Cell Biol 201: 929-944. CrossRef Medline

Yim YS, Kwon Y, Nam J, Yoon HI, Lee K, Kim DG, Kim E, Kim CH, Ko J (2013) Slitrks control excitatory and inhibitory synapse formation with LAR receptor protein tyrosine phosphatases. Proc Natl Acad Sci U S A 110:4057-4062. CrossRef Medline 